\title{
Tunable Lossy and Lossless Grounded Inductors Using Minimum Active and Passive Components
}

\author{
Tapas Kumar Paul, Suvajit Roy, Radha Raman Pal* \\ Department of Physics, Vidyasagar University, Midnapore, India \\ Received 21 March 2021; received in revised form 06 May 2021; accepted 07 May 2021 \\ DOI: https://doi.org/10.46604/ijeti.2021.7354
}

\begin{abstract}
In this contribution, nine new Grounded Inductance Simulators (GISs) using a single Multiple-Output Current Controlled Current Conveyor Transconductance Amplifier (MO-CCCCTA) and one grounded capacitor are proposed. Among them, two are lossless types and seven are lossy types. The use of a single grounded capacitor makes the circuits suitable for fabrication. All the proposed circuits are electronically tunable through the bias currents of MO-CCCCTA. Furthermore, no component matching conditions are needed for realizing them. The designed circuits are verified through PSPICE simulator with $\pm 0.9 \mathrm{~V}$ power supply. The simulation results show that for all the proposed circuits: maximum operating frequencies are about $12 \mathrm{MHz}$, power dissipation is less than 0.784 $\mathrm{mW}$, Total Harmonic Distortions (THDs) are under 8.09\%, and maximum output voltage noise at $1 \mathrm{MHz}$ frequency is $14.094 \mathrm{nV} / \sqrt{ } \mathrm{Hz}$. To exhibit the workability of the proposed circuits, they are used to design band-pass, low-pass filter, parallel RLC resonator, and parasitic inductance cancelator.
\end{abstract}

Keywords: active inductor, multiple-output current controlled current conveyor transconductance amplifier (MO-CCCCTA), electronic controllability, filters, resonant circuit

\section{Introduction}

Recently, the implementation of inductors using different active building blocks has received much attention as the implementation of passive spiral inductors in an integrated circuit is difficult. The passive inductors consume a large chip area and also suffer from resistive losses and process variabilities. Inductor simulators are used in electronics, instrumentation, measurement, and communication systems. It finds applications in analog active filters and LC oscillators for impedance matching, phase shifters, and parasitic cancellation [1-3].

In the past, several Grounded Inductor Simulators (GISs) were reported using active building blocks, such as Dual X Current Conveyor Differential Input Transconductance Amplifier (DXCCDITA) [1], Modified Differential Voltage Current Conveyor (MDVCC) [2], Voltage Differencing Current Conveyor (VDCC) [3], Dual X Second-Generation Current Conveyor (DXCCII) [4-6], Plus-Type Second Generation Current Conveyor (CCII+) and Inverting Voltage Buffer (IVB) [7], Dual X Current Conveyor Transconductance Amplifier (DXCCTA) [8], Current Differencing Transconductance Amplifier (CDTA) [9], Current Controlled Current Conveyor Transconductance Amplifier (CCCCTA) [10], Current Differencing Buffered Amplifier (CDBA) [11-12], Four Terminal Floating Nullor Transconductance Amplifier (FTFNTA) [13], Voltage Differencing Gain Amplifier (VDGA) [14], Current-Controlled-Current-Feedback Amplifier (CC-CFA) [15], Current Follower Current Controlled Conveyor (CFCCC) [16], Voltage Differencing Transconductance Amplifier (VDTA) [17-19], Z-Copy Current-Controlled Current Inverting Transconductance Amplifier (ZC-CCCITA) [20], Extra X Current Conveyor

*Corresponding author. E-mail address: rrpal@mail.vidyasagar.ac.in 
Transconductance Amplifier (EXCCTA) [21], Operational Transresistance Amplifier (OTRA) [22-26], Voltage Differencing Inverting Buffered Amplifier (VDIBA) [27-28], Voltage Differencing Buffered Amplifier (VDBA) [29], etc. Among the inductance simulators, most of the configuration comes with two or more passive components for implementation [1-8, 11-13, 21-26, 29]. Two or more active building blocks are required in [9, 15, 25-26, 28]. The inductors proposed in [4-6, 12, 22-23, 25] require matching conditions between passive components. The work described in [2-29] realize only lossless/lossy/negative inductance simulators. Floating components are required in [1-2, 4-7, 11-12, 22-29]. Additionally, the circuits of [2, 4-7, 11-12, 22-26] cannot be tuned electronically. The vigorous study of this literature gives a scope for realizing inductors for both lossy and lossless inductors that use single active block and single capacitor without component matching conditions, and can offer the electronically tunable facility.

In this research, nine new GISs are proposed. All the proposed inductors are composed of a single active block and single grounded capacitor in each design. Furthermore, the inductors do not require component matching conditions, and the inductors can be tuned electronically. To test the workability of the lossless inductor simulator circuits, the positive inductor is used to design a Band-Pass (BP) filter, the negative inductor is used to cancel parasitic inductance, lossy series RL circuit is used to design a Low-Pass (LP) filter, and lossy parallel RL circuit is used to design parallel resonant circuit.

This study has been divided as follows: The introduction is presented in section 1, and Multiple-Output Current Controlled Current Conveyor Transconductance Amplifier (MO-CCCCTA) is introduced in section 2. Section 3 describes the configurations of the proposed GISs. The non-ideal analysis of the proposed configurations is performed in section 4. Section 5 brings simulation results. After that, the applications of the reported inductors are presented in section 6 followed by section 7 where the comparisons of the proposed inductors with the previous publication are discussed. Finally, the study is concluded in section 8 .

\section{MO-CCСCTA}

MO-CCCCTA is a versatile active building block which is effective to simplify the circuit configuration. The most attractive feature of this block is that it requires no resistor in practical applications as it has parasitic resistance. The port relations of MO-CCCCTA block can be characterized as:

$$
\left[\begin{array}{c}
V_{X} \\
I_{Y} \\
I_{Z} \\
I_{O \pm}
\end{array}\right]=\left[\begin{array}{ccc}
R_{X} & 0 & 1 \\
0 & 0 & 0 \\
1 & 0 & 0 \\
0 & \pm g_{m} & 0
\end{array}\right]\left[\begin{array}{c}
I_{X} \\
V_{Z} \\
V_{Y}
\end{array}\right]
$$

where $R_{X}$ is the parasitic resistance at X-port and $g_{m}$ is the transconductance gain of MO-CCCCTA. The parasitic resistance $R_{X}$ and transconductance gain $g_{m}$ are electronically tunable through the input bias currents $I_{B}$ and $I_{S}$, respectively. The circuit symbol and the equivalent circuit of the MO-CCCCTA block are shown in Fig. 1 [30]. The Complementary Metal-Oxide-Semiconductor (CMOS) implementation of MO-CCCCTA is shown in Fig. 2. It consists of two principal blocks: a Current Controlled Second Generation Current Conveyor (CCCII) circuit and an Operational Transconductance Amplifier (OTA) circuit. The circuit implementation consists of mixed translinear loop (M1-M4). The mixed loop is DC biased by using current mirrors (M5-M6 and M9-M11). The output Z-terminal that generates the current from $X$ terminal is realized using transistors (M7-M8 and M12-M13). The simple-version transconductance amplifier is realized using transistors (M14-M15, M18-M21, and M23-M24). The inverted output terminals (O-) are realized by using transistors (M16-M17, M22, and M25-M27). 


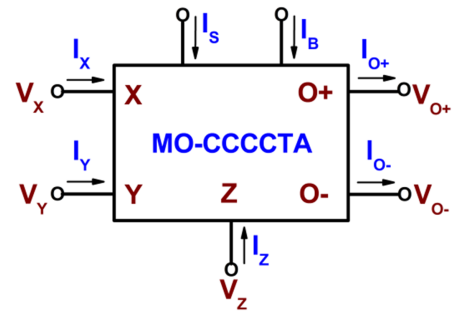

(a) Symbol

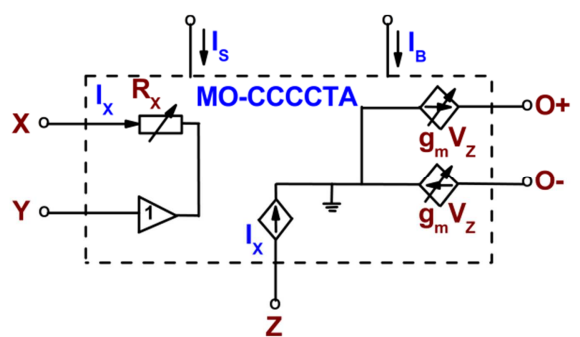

(b) Equivalent circuit

Fig. 1 MO-CCCCTA [30]

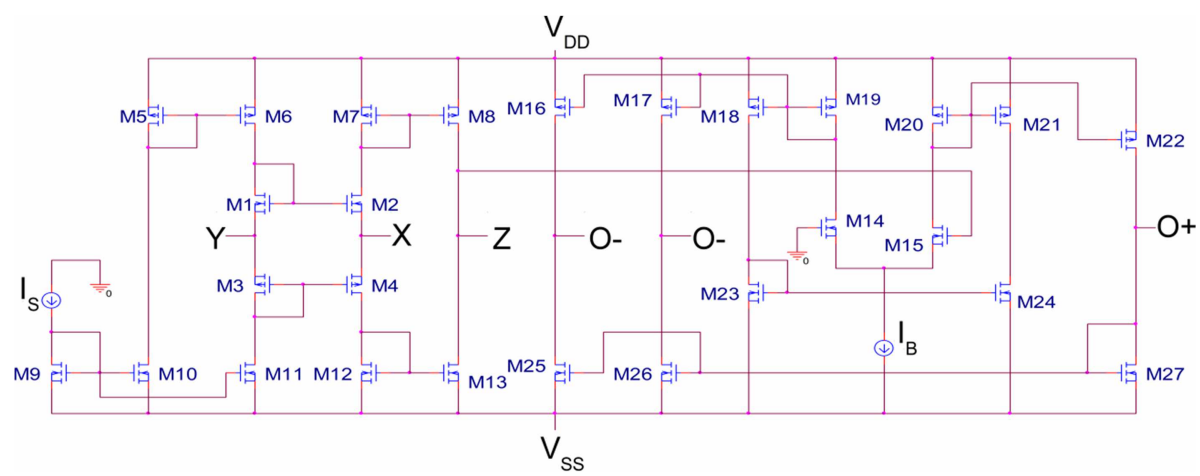

Fig. 2 CMOS implementation of MO-CCCCTA [30]

\section{The Proposed GISs}

The proposed GISs using a single active block and single capacitor are shown in Fig. 3. The use of a single grounded capacitor for all the configurations makes the circuits suitable for fabrication. Furthermore, it is also beneficial in stopping noise and parasitic effects [1]. Among the nine topologies, the first two circuits provide lossless (positive and negative inductors) and the rest seven circuits can realize lossy inductors. The input impedances along with equivalent inductances and equivalent resistances obtained by routine analysis of these configurations are summarized in Table 1 . The sensitivities of the inductors can be expressed as:

$$
S_{C, R_{X}}^{L_{e q}}=-S_{g_{m}}^{L_{e q}}=1
$$

From Eq. (2), it is seen that the sensitivities of the inductors are low and not more than unity.

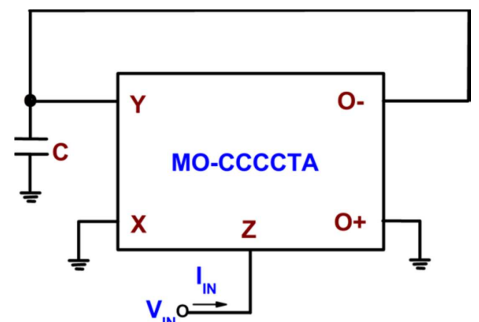

(a) GIS-1

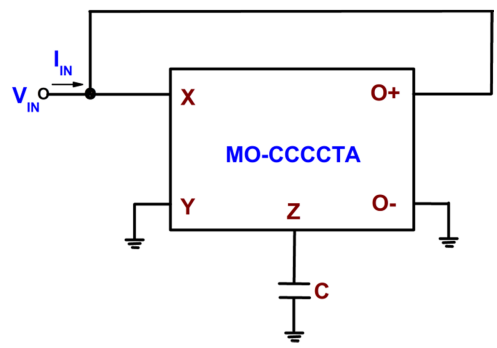

(d) GIS-4

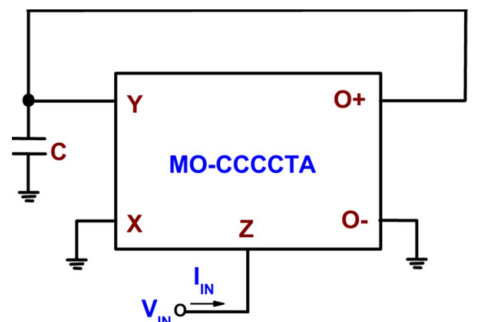

(b) GIS-2

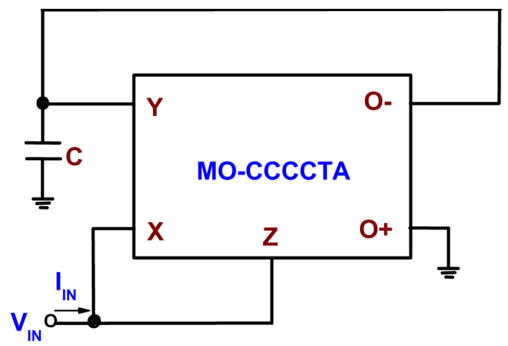

(e) GIS-5

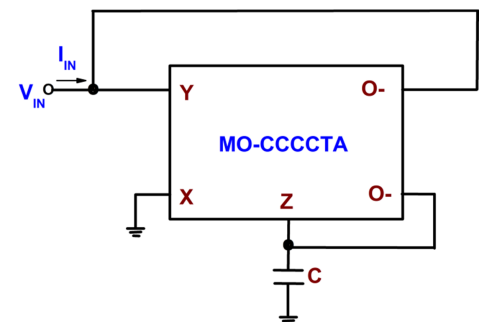

(c) GIS-3

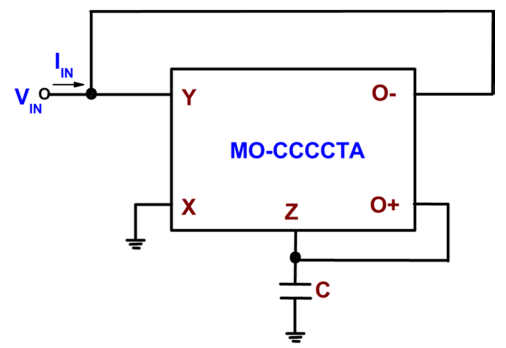

(f) GIS-6

Fig. 3 The proposed lossless and lossy GIS circuits 


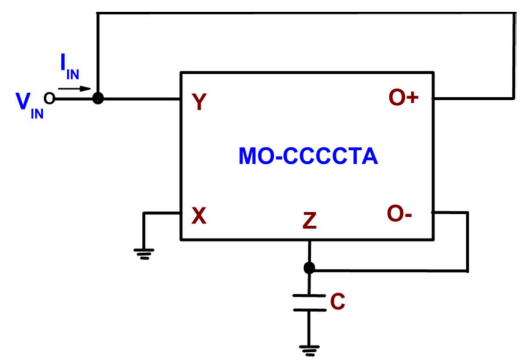

(g) GIS-7

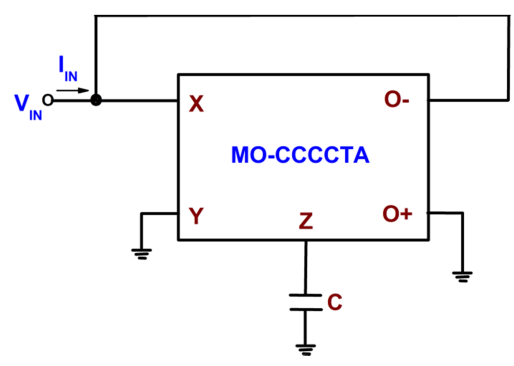

(h) GIS-8

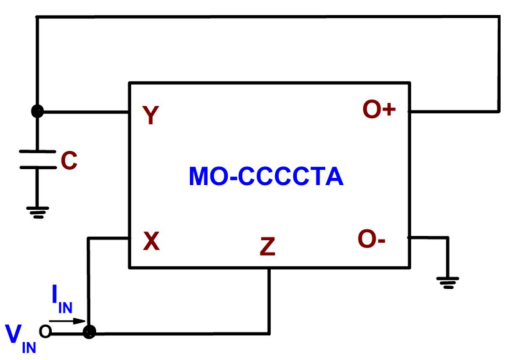

(i) GIS-9

Fig. 3 The proposed lossless and lossy GIS circuits (continued)

Table 1 The actively realizable inductance constructions

\begin{tabular}{|c|c|c|c|c|c|}
\hline Circuit & Simulator & Type & Impedance realized & $\mathrm{L}_{\mathrm{eq}}$ & $\mathrm{R}_{\mathrm{eq}}$ \\
\hline Fig. 3(a) & GIS-1 & Pure L & $\frac{s C R_{X}}{\mathrm{~g}_{m}}$ & $\frac{C R_{X}}{\mathrm{~g}_{m}}$ & - \\
\hline Fig. 3(b) & GIS-2 & Pure L & $-\frac{s C R_{X}}{\mathrm{~g}_{m}}$ & $-\frac{C R_{X}}{\mathrm{~g}_{m}}$ & - \\
\hline Fig. 3(c) & GIS-3 & + L series with + R & $\frac{s C R_{X}}{\mathrm{~g}_{m}}+R_{X}$ & $\frac{C R_{X}}{\mathrm{~g}_{m}}$ & $R_{X}$ \\
\hline Fig. 3(d) & GIS-4 & + L parallel with + R & $\frac{1}{\mathrm{~g}_{m}}+\frac{1}{R_{X}}$ & $\frac{C R_{X}}{\mathrm{~g}_{m}}$ & $R_{X}$ \\
\hline Fig. 3(e) & GIS-5 & + L parallel with + R & $\frac{1}{2 \mathrm{~g}_{m}}+\frac{2}{R_{X}}$ & $\frac{C R_{X}}{2 \mathrm{~g}_{m}}$ & $\frac{R_{X}}{2}$ \\
\hline Fig. 3(f) & GIS-6 & + L series with $-\mathrm{R}$ & $\frac{s C R_{X}}{\mathrm{~g}_{m}}-R_{X}$ & $\frac{C R_{X}}{\mathrm{~g}_{m}}$ & $-R_{X}$ \\
\hline Fig. 3(g) & GIS-7 & - L series with $-\mathrm{R}$ & $-\frac{s C R_{X}}{\mathrm{~g}_{m}}-R_{X}$ & $-\frac{C R_{X}}{\mathrm{~g}_{m}}$ & $-R_{X}$ \\
\hline Fig. 3(h) & GIS-8 & - L parallel with + R & $\frac{1}{-\frac{\mathrm{g}_{m}}{s C R_{X}}+\frac{1}{R_{X}}}$ & $-\frac{C R_{X}}{\mathrm{~g}_{m}}$ & $R_{X}$ \\
\hline Fig. & GIS-9 & $-\mathrm{L}$ parallel with + R & $\frac{2 \mathrm{~g}_{m}}{s C R_{X}}+\frac{2}{R_{X}}$ & $-\frac{C R_{X}}{2 \mathrm{~g}_{m}}$ & $\frac{R_{X}}{2}$ \\
\hline
\end{tabular}

\section{Non-Ideal Analysis}

For MO-CCCCTA, the non-ideal characteristic equations are expressed as:

$$
\begin{aligned}
& V_{X}=\beta V_{Y}+I_{X} R_{X} \\
& I_{Z}=\alpha I_{X} \\
& I_{O+}=\gamma_{P} g_{m} V_{Z} \\
& I_{O 1-}=-\gamma_{N} g_{m} V_{Z} \\
& I_{O 2-}=-\gamma_{N C} g_{m} V_{Z}
\end{aligned}
$$

where $\beta, \alpha, \gamma_{P}, \gamma_{N}$, and $\gamma_{N C}$ are the transfer ratios and ideally equal to unity.

In addition, like any other active device, a practical MO-CCCCTA shows various terminals parasitic. The parasitic model of MO-CCCCTA is shown in Fig. 4. It shows that a small series resistance $R_{X}$ appears at X terminal, whereas the parasites in the form of shunt output impedances $\left(R_{Y} / / C_{Y}\right),\left(R_{Z} / / C_{Z}\right),\left(R_{O_{+}} / / C_{O_{+}}\right)$, and $\left(R_{O i} / / C_{O i_{-}}\right)$appear at $\mathrm{Y}, \mathrm{Z}, \mathrm{O}+$, and $\mathrm{O}_{\mathrm{i}-}$ ports $(\mathrm{i}=1,2)$, 
respectively. After considering these parasitic impedances and considering the non-ideal gains, on the proposed circuits, the input impedance of the inductors has been reanalyzed and expressed in Table 2. Though it is noted from Table 2 that the impedances are influenced owing to the inclusion of MO-CCCCTA parasitic and non-ideal transfer current gains, it is not excessive as $R_{Y}, R_{Z}, R_{O+}$, and $R_{O-}$ are very high, $C_{Y}, C_{Z}, C_{O+}, C_{O I_{-}}$, and $C_{O 2-}$ are very low, and $\alpha, \beta, \gamma_{P}, \gamma_{N}$, and $\gamma_{N C}$ are very close to unity.

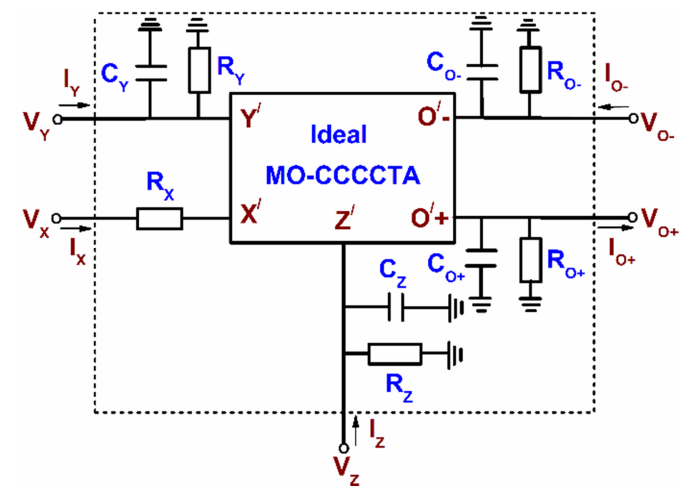

Fig. 4 Non-ideal model of MO-CCCCTA

Table 2 Impedance of the proposed inductors including non-ideal gains and parasitic impedances

\begin{tabular}{|c|c|c|}
\hline Simulator & Impedance realized & Assumed values \\
\hline GIS-1 & $\frac{s C_{E}+\frac{1}{R_{E}}}{\frac{\alpha \beta \gamma_{N} g_{m}}{R_{X}}+\left(s C_{E}+\frac{1}{R_{E}}\right)\left(s C_{Z}+\frac{1}{R_{Z}}\right)}$ & $\mathrm{C}_{\mathrm{E}}=\mathrm{C}+\mathrm{C}_{\mathrm{Y}}+\mathrm{C}_{\mathrm{O}-} ; \mathrm{R}_{\mathrm{E}}=\mathrm{R}_{\mathrm{Y}} \| \mathrm{R}_{\mathrm{O}-}$ \\
\hline GIS-2 & $\frac{s C_{E}+\frac{1}{R_{E}}}{-\frac{\alpha \beta \gamma_{P} \mathrm{~g}_{m}}{R_{X}}+\left(s C_{E}+\frac{1}{R_{E}}\right)\left(s C_{Z}+\frac{1}{R_{Z}}\right)}$ & $\mathrm{C}_{\mathrm{E}}=\mathrm{C}+\mathrm{C}_{\mathrm{Y}}+\mathrm{C}_{\mathrm{O}+} ; \mathrm{R}_{\mathrm{E}}=\mathrm{R}_{\mathrm{Y}} \| \mathrm{R}_{\mathrm{O}+}$ \\
\hline GIS-3 & $\frac{s C_{E 2}+\gamma_{N C} \mathrm{~g}_{m}+\frac{1}{R_{E 2}}}{\frac{\alpha \beta \gamma_{N} \mathrm{~g}_{m}}{R_{X}}+\left(s C_{E 1}+\frac{1}{R_{E 1}}\right)\left(s C_{E 2}+\mathrm{g}_{m}+\frac{1}{R_{E 2}}\right)}$ & $\begin{array}{c}\mathrm{C}_{\mathrm{E} 1}=\mathrm{C}_{\mathrm{Y}}+\mathrm{C}_{\mathrm{O} 1-} ; \mathrm{R}_{\mathrm{E} 1}=\mathrm{R}_{\mathrm{Y}} \| \mathrm{R}_{\mathrm{O} 1-} \\
\mathrm{C}_{\mathrm{E} 2}=\mathrm{C}+\mathrm{C}_{\mathrm{Z}}+\mathrm{C}_{\mathrm{O} 2-} ; \mathrm{R}_{\mathrm{E} 2}=\mathrm{R}_{\mathrm{Z}} \| \mathrm{R}_{\mathrm{O} 2-}\end{array}$ \\
\hline GIS-4 & $\frac{1}{\frac{\alpha \gamma_{P} g_{m}}{\left(s C_{E}+\frac{1}{R_{Z}}\right) R_{X}}+\frac{1}{R_{X}}+\left(s C_{O+}+\frac{1}{R_{O+}}\right)}$ & $\mathrm{C}_{\mathrm{E}}=\mathrm{C}+\mathrm{C}_{\mathrm{Z}}$ \\
\hline GIS-5 & $\frac{1}{\frac{(1+\alpha) \beta \gamma_{N} g_{m}}{\left(s C_{E}+\frac{1}{R_{E}}\right) R_{X}}+\frac{(1+\alpha)}{R_{X}}+\left(s C_{Z}+\frac{1}{R_{Z}}\right)}$ & $\mathrm{C}_{\mathrm{E}}=\mathrm{C}+\mathrm{C}_{\mathrm{Y}}+\mathrm{C}_{\mathrm{O}-} ; \mathrm{R}_{\mathrm{E}}=\mathrm{R}_{\mathrm{Y}} \| \mathrm{R}_{\mathrm{O}-}$ \\
\hline GIS-6 & $\frac{s C_{E 2}-\gamma_{P} g_{m}+\frac{1}{R_{E 2}}}{\frac{\alpha \beta \gamma_{N} g_{m}}{R_{X}}-\left(s C_{E 1}+\frac{1}{R_{E 1}}\right)\left(s C_{E 2}+\gamma_{P} g_{m}+\frac{1}{R_{E 2}}\right)}$ & $\begin{array}{c}\mathrm{C}_{\mathrm{E} 1}=\mathrm{C}_{\mathrm{Y}}+\mathrm{C}_{\mathrm{O}-} ; \mathrm{R}_{\mathrm{E} 1}=\mathrm{R}_{\mathrm{Y}} \| \mathrm{R}_{\mathrm{O}-} \\
\mathrm{C}_{\mathrm{E} 2}=\mathrm{C}+\mathrm{C}_{\mathrm{Z}}+\mathrm{C}_{\mathrm{O}+} ; \mathrm{R}_{\mathrm{E} 2}=\mathrm{R}_{\mathrm{Z}} \| \mathrm{R}_{\mathrm{O}+}\end{array}$ \\
\hline GIS-7 & $\frac{s C_{E 2}+\gamma_{N} \mathrm{~g}_{m}+\frac{1}{R_{E 2}}}{-\frac{\alpha \beta \gamma_{P} \mathrm{~g}_{m}}{R_{X}}+\left(s C_{E 1}+\frac{1}{R_{E 1}}\right)\left(s C_{E 2}+\gamma_{N} \mathrm{~g}_{m}+\frac{1}{R_{E 2}}\right)}$ & $\begin{array}{c}\mathrm{C}_{\mathrm{E} 1}=\mathrm{C}_{\mathrm{Y}}+\mathrm{C}_{\mathrm{O}+} ; \mathrm{R}_{\mathrm{E} 1}=\mathrm{R}_{\mathrm{Y}} \| \mathrm{R}_{\mathrm{O}+} \\
\mathrm{C}_{\mathrm{E} 2}=\mathrm{C}+\mathrm{C}_{\mathrm{Z}}+\mathrm{C}_{\mathrm{O}-} ; \mathrm{R}_{\mathrm{E} 2}=\mathrm{R}_{\mathrm{Z}} \| \mathrm{R}_{\mathrm{O}-}\end{array}$ \\
\hline GIS-8 & $\frac{1}{-\frac{\alpha \gamma_{N} \mathrm{~g}_{m}}{\left(s C_{E}+\frac{1}{R_{Z}}\right) R_{X}}+\frac{1}{R_{X}}+\left(s C_{O-}+\frac{1}{R_{O-}}\right)}$ & $\mathrm{C}_{\mathrm{E}}=\mathrm{C}+\mathrm{C}_{\mathrm{Z}}$ \\
\hline GIS-9 & $\frac{1}{-\frac{(1+\alpha) \beta \gamma_{P} \mathrm{~g}_{m}}{\left(s C_{E}+\frac{1}{R_{E}}\right) R_{X}}+\frac{(1+\alpha)}{R_{X}}+\left(s C_{Z}+\frac{1}{R_{Z}}\right)}$ & $\mathrm{C}_{\mathrm{E}}=\mathrm{C}+\mathrm{C}_{\mathrm{Y}}+\mathrm{C}_{\mathrm{O}+} ; \mathrm{R}_{\mathrm{E}}=\mathrm{R}_{\mathrm{Y}} \| \mathrm{R}_{\mathrm{O}+}$ \\
\hline
\end{tabular}




\section{Simulation Results}

Simulations have been carried out using the CMOS implementation of MO-CCCCTA as depicted in Fig. 2 through PSPICE simulator with TSMC $0.18 \mu \mathrm{m}$ process parameters. The aspect ratios of the transistors are given in Table 3 . The supply voltages are chosen as $\mathrm{V}_{\mathrm{DD}}=-\mathrm{V}_{\mathrm{SS}}=0.9 \mathrm{~V}$. The proposed GISs 1-4 are simulated with capacitor value $50 \mathrm{pF}$. The bias current values are $I_{S}=7.113 \mu \mathrm{A}\left(\mathrm{R}_{\mathrm{x}}=5 \mathrm{k} \Omega\right)$ and $I_{B}=24.135 \mu \mathrm{A}\left(\mathrm{g}_{\mathrm{m}}=100 \mu \mathrm{S}\right)$ for all the simulations.

Table 3 The dimensions of the Metal-Oxide-Silicon (MOS) transistors utilized in the MO-CCCCTA architecture [30]

\begin{tabular}{|c|c|}
\hline Transistor & $\mathrm{W} / \mathrm{L}(\mu \mathrm{m} / \mu \mathrm{m})$ \\
\hline M1, M2 & $5 / 0.18$ \\
\hline M3, M4 & $8 / 0.18$ \\
\hline M5-M8 & $5 / 0.18$ \\
\hline M9-M13 & $3 / 0.18$ \\
\hline M14, M15 & $10 / 0.5$ \\
\hline M16-M22 & $25 / 0.8$ \\
\hline M23-M27 & $8 / 0.8$ \\
\hline
\end{tabular}

The ideal and simulated magnitude and corresponding inductance value versus frequency curves of the lossless inductor (GIS-1 and GIS-2) are given in Figs. 5(a)-(b), respectively. It is observed that the simulated and the ideal responses are nearly equal to each other in the frequency range of $20 \mathrm{kHz}$ to $12 \mathrm{MHz}$. The ideal and simulated phase responses are shown in Fig. 6. The simulated phase values for GIS- 1 are $86.85^{\circ}$ at $20 \mathrm{kHz}$ and $98.08^{\circ}$ at $12 \mathrm{MHz}$, so the calculated errors are $3.5 \%$ and $8.97 \%$, respectively. The same for GIS-2 are $95.52^{\circ}$ and $98.95^{\circ}$ respectively with corresponding errors of $6.13 \%$ and $9.94 \%$. To measure the phase difference between current and voltage for GIS-1 and GIS-2, transient analyses have been done as shown in Fig. 7. The obtained phase differences are 92 degree and 93 degree for GIS-1 and GIS-2, so the calculated error is $2.22 \%$ and $3.33 \%$, respectively.

The tunability of the recommended GIS-1 and GIS-2 has been confirmed by varying the bias currents. The resulting magnitude curve for GIS-1 is displayed in Fig. 8, whereas the resulting magnitude curves for GIS-2 are shown in Fig. 9. The corresponding inductor value of GIS-1 and GIS-2 are shown in Figs. 10 and 11, respectively. It is found that between $20 \mathrm{kHz}$ and $12 \mathrm{MHz}$, changes of impedances are linear, thus simulated inductances are assumed to be constant for this interval. The inductance values at $1 \mathrm{MHz}$ frequency for the GIS-1 and GIS-2 obtained from the theoretical expectation and simulation are given in Table 4. Variation of phase for different bias currents has also been simulated. Fig. 12 shows the phase variation of GIS-1 with different bias currents. Phase variation of GIS-2 is shown in Fig. 13. It is proved that the values of the inductors can be tuned by input bias currents $I_{B}$ and $I_{S}$.

The simulated Total Harmonic Distortion (THD) of GIS-1 and GIS-2 for different input currents are shown in Fig. 14. The results show that the maximum THDs up to $70 \mu \mathrm{A}$ are $8.09 \%$ and $2.69 \%$ for the GIS-1 and GIS-2, respectively. Finally, Monte Carlo analysis for $10 \%$ deviation in capacitor value is done for 100 runs to study the effect of process variability on the response of the simulator as presented in Fig. 15. It illustrates that the magnitude of inductances vary from $2.4379 \mathrm{mH}$ to $2.68695 \mathrm{mH}$ with a mean value of $2.5658 \mathrm{mH}$ for the GIS-1 and for the GIS-2, it is from $2.41266 \mathrm{mH}$ to $2.65626 \mathrm{mH}$ with the mean value of 2.53878 $\mathrm{mH}$. The noise behavior of the inductance simulator of GIS-1 and GIS-2 with respect to frequency has been shown in Fig. 16. The output voltage noise and equivalent input current noise of GIS-1 at the frequency of $1 \mathrm{MHz}$ are calculated as $12.501 \mathrm{nV} / \sqrt{\mathrm{Hz}}$ and $2.306 \mathrm{pA} / \sqrt{\mathrm{Hz}}$, respectively. For GIS-2, the same are $12.467 \mathrm{nV} / \sqrt{ } \mathrm{Hz}$ and $2.266 \mathrm{pA} / \sqrt{\mathrm{Hz}}$, respectively.

Next, the GIS-3 and GIS-4 are simulated. The theoretical and the simulated magnitude and phase responses for the input impedance of GIS-3 are given in Fig. 17. The electronic tunability of GIS-3 is shown in Fig. 18, whereas the variation of phase with frequency is shown in Fig. 19. The noise behavior of the GIS-3 with respect to frequency is displayed in Fig. 20. The calculated output voltage noise at $1 \mathrm{MHz}$ frequency is $12.059 \mathrm{nV} / \sqrt{\mathrm{Hz}}$ and the input referred noise is $2.369 \mathrm{pA} / \sqrt{\mathrm{Hz}}$. 


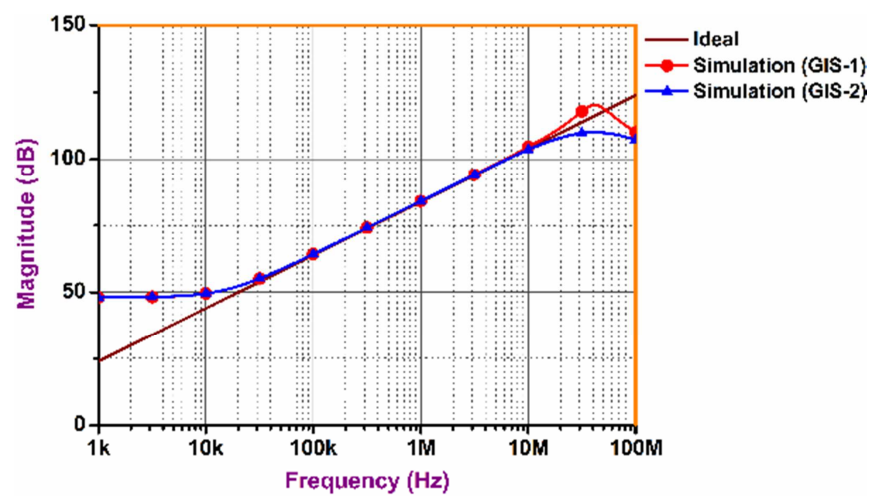

(a) Impedances magnitude

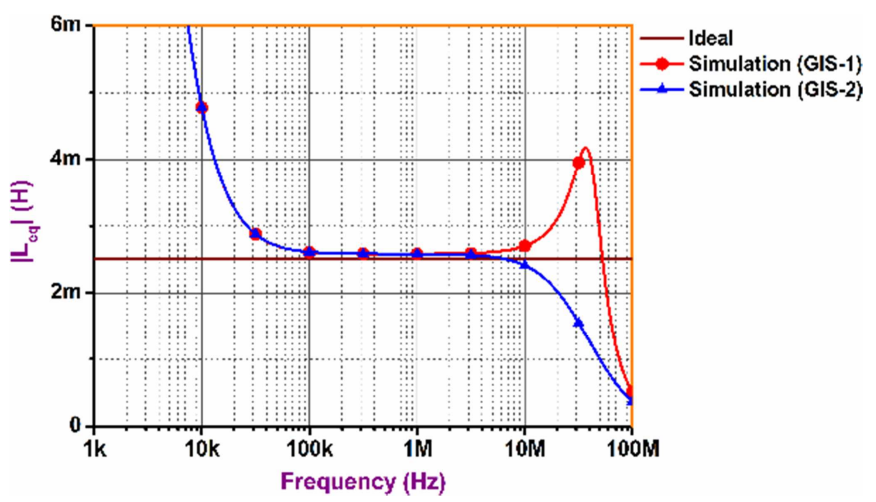

(b) Inductance values

Fig. 5 Frequency responses for the proposed lossless inductors

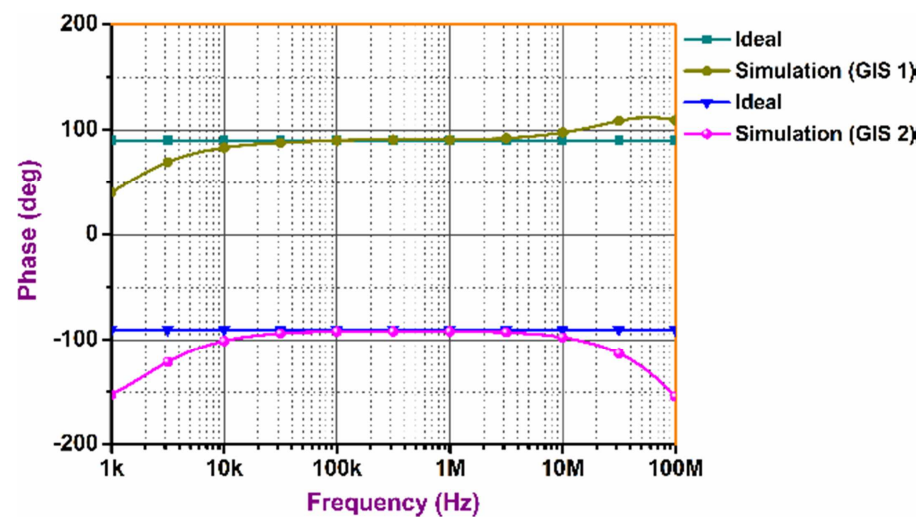

Fig. 6 Frequency responses of the phase for the proposed lossless inductors

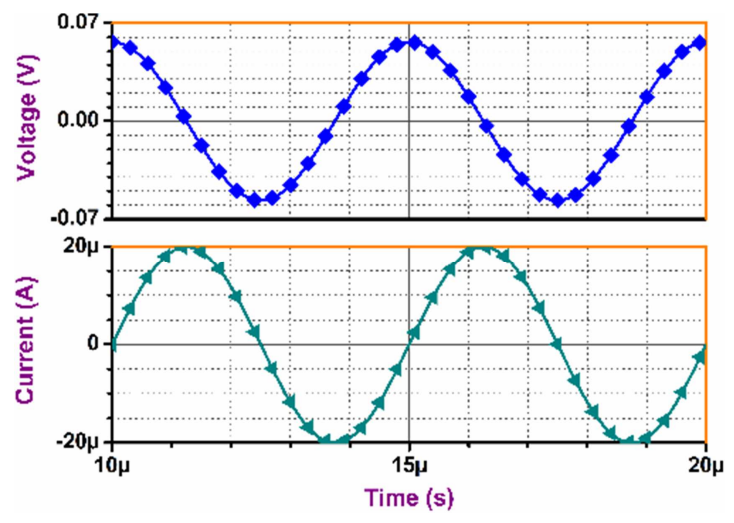

(a) For GIS-1
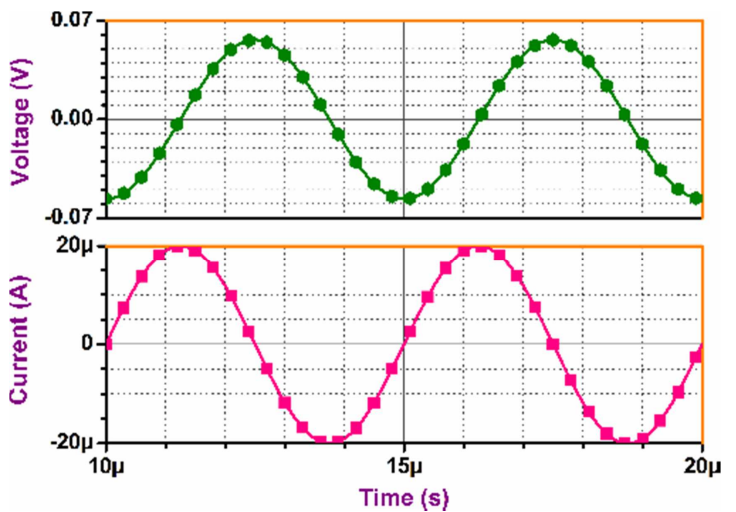

(b) For GIS-2

Fig. 7 The transient analysis output

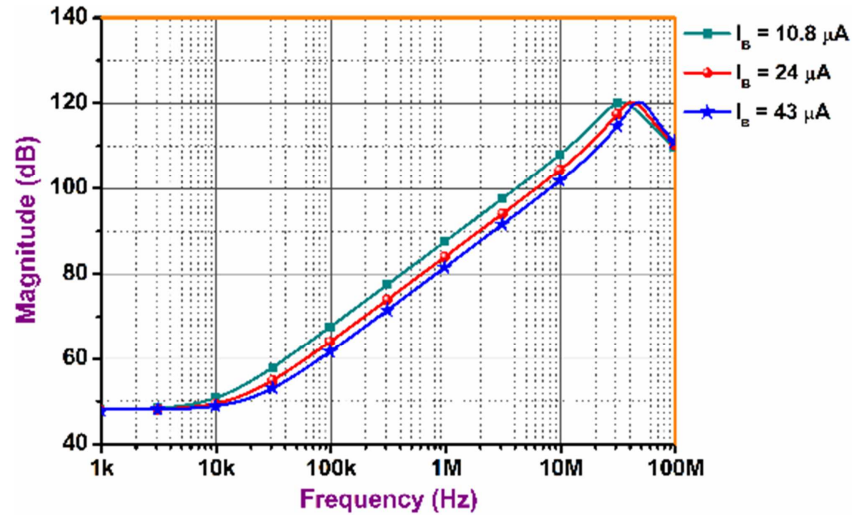

(a) With $I_{B}$

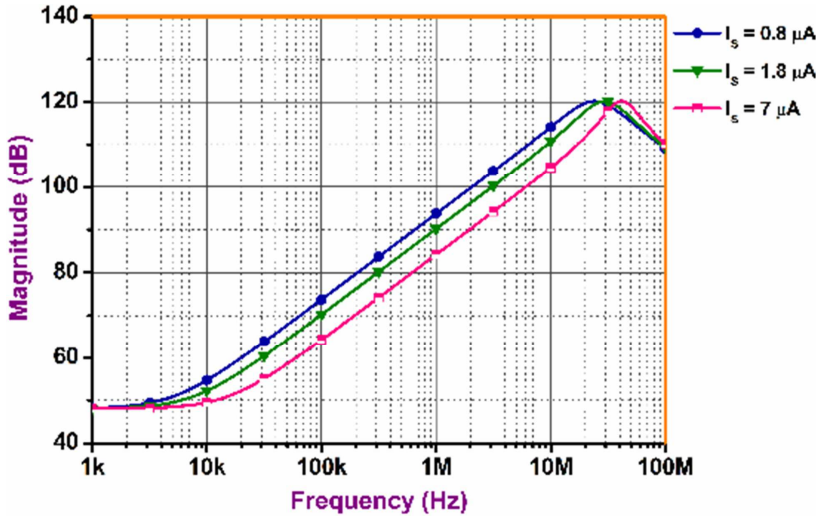

(b) With $I_{S}$

Fig. 8 Variation of impedance magnitude for GIS-1 


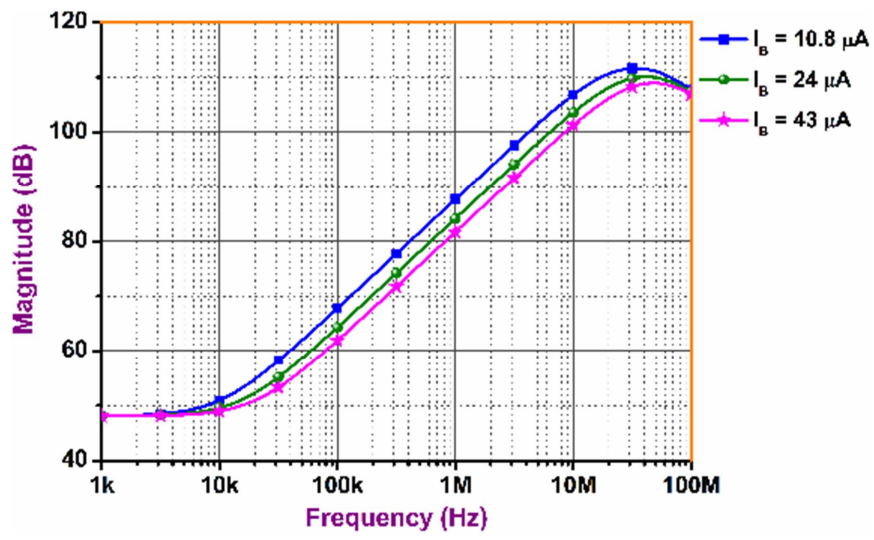

(a) With $I_{B}$

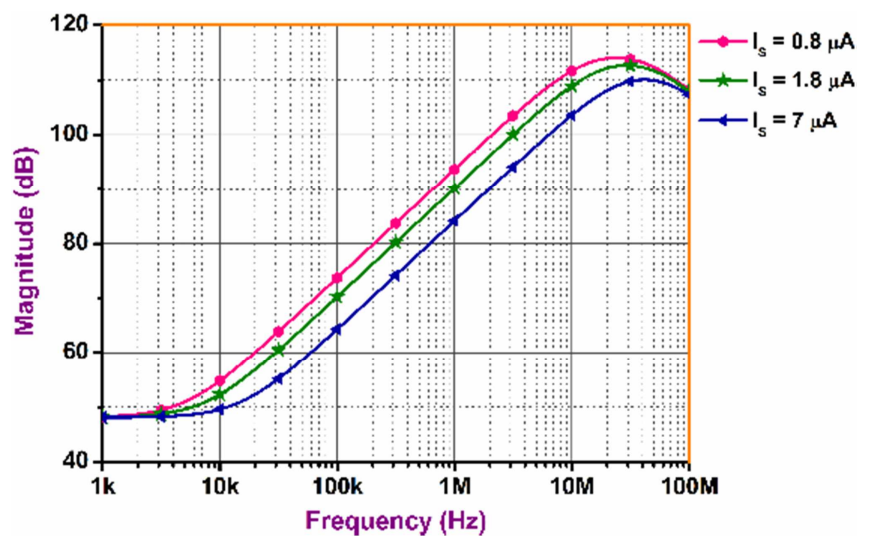

(b) With $I_{S}$

Fig. 9 Variation of impedance magnitude for GIS-2

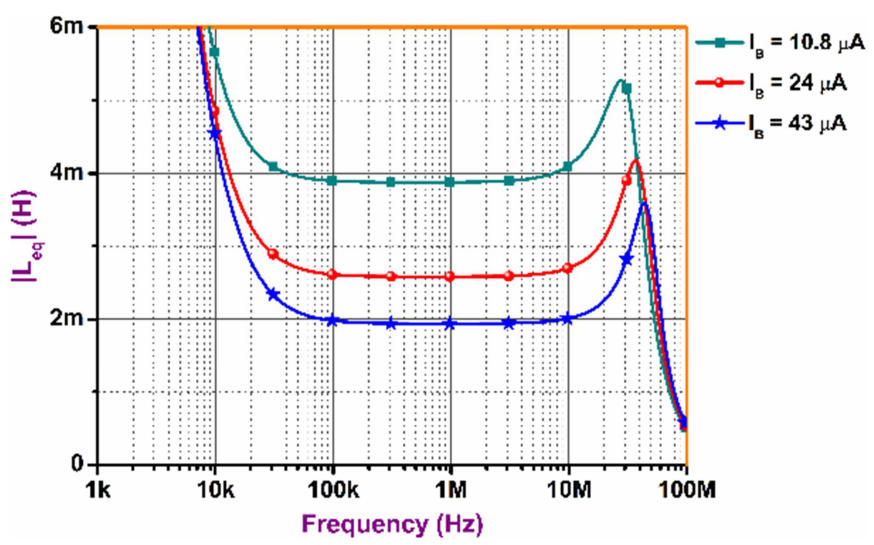

(a) With $I_{B}$

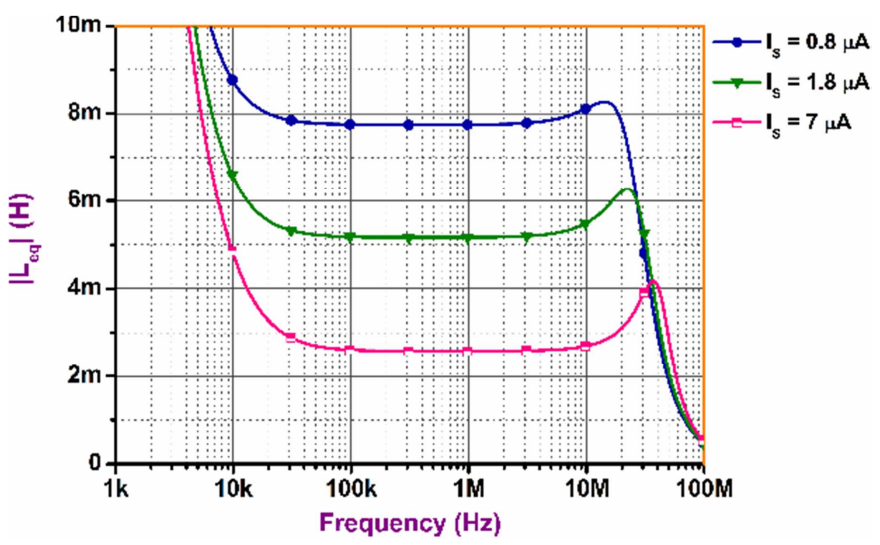

(b) With $I_{S}$

Fig. 10 Variation of inductance for GIS-1

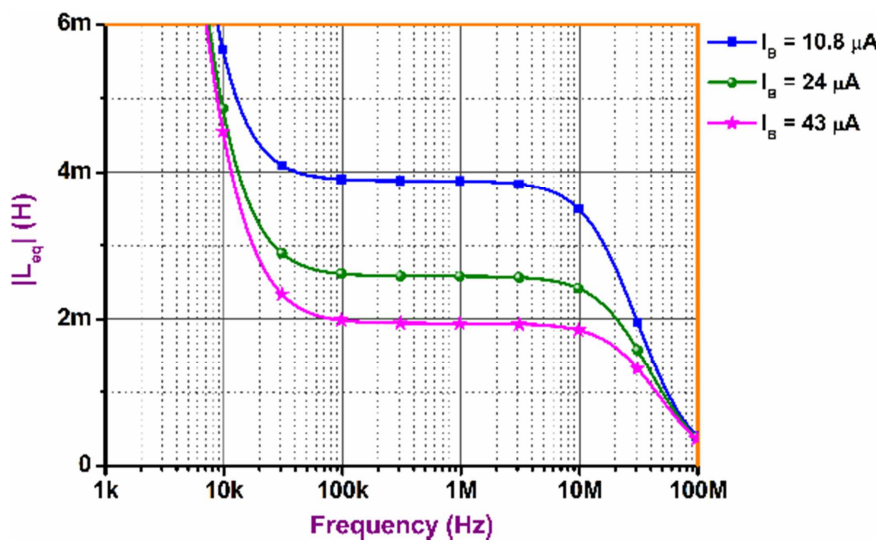

(a) With $I_{B}$

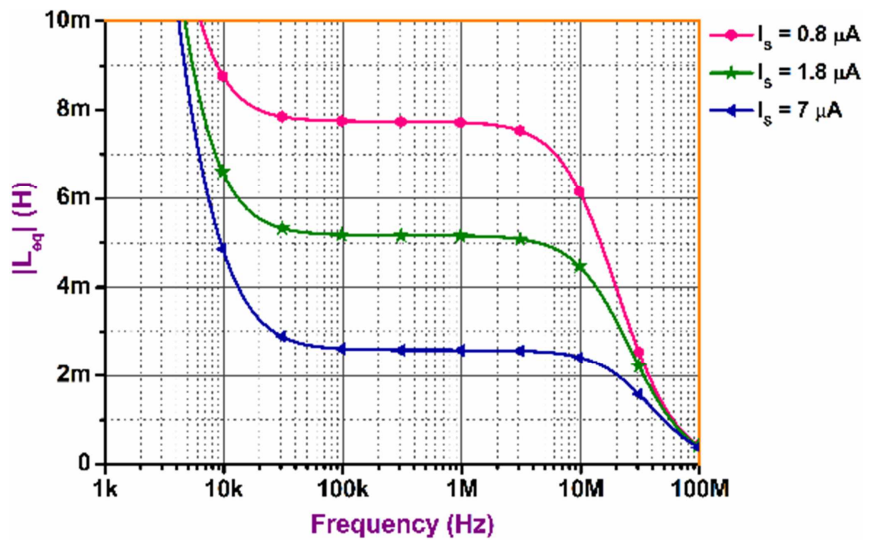

(b) With $I_{S}$

Fig. 11 Variation of inductance for GIS-2

Table 4 Theoretical and simulated inductor values with percentage errors for lossless inductance simulators

\begin{tabular}{|c|c|c|c|c|c|}
\hline \multirow{2}{*}{$\begin{array}{c}\text { Bias current } \\
(\mu \mathrm{A})\end{array}$} & $\begin{array}{c}\text { Theoretical value } \\
(\mathrm{mH})\end{array}$ & \multicolumn{2}{|c|}{ GIS-1 } & \multicolumn{2}{c|}{ GIS-2 } \\
\cline { 3 - 6 } & 3.75 & Simulated value $(\mathrm{mH})$ & Error $(\%)$ & Simulated value $(\mathrm{mH})$ & Error $(\%)$ \\
\hline$I_{B}=10.8$ & 2.5 & 2.88 & 3.46 & 3.88 & 3.46 \\
\hline$I_{B}=24$ & 1.88 & 1.94 & 3.20 & 2.58 & 3.20 \\
\hline$I_{B}=43$ & 7.5 & 7.78 & 3.19 & 1.94 & 3.19 \\
\hline$I_{S}=0.8$ & 5 & 5.16 & 3.20 & 7.72 & 2.93 \\
\hline$I_{S}=1.8$ & 2.5 & 2.58 & 3.20 & 5.15 & 3.00 \\
\hline$I_{S}=7$ & & & & 2.58 & 3.20 \\
\hline
\end{tabular}




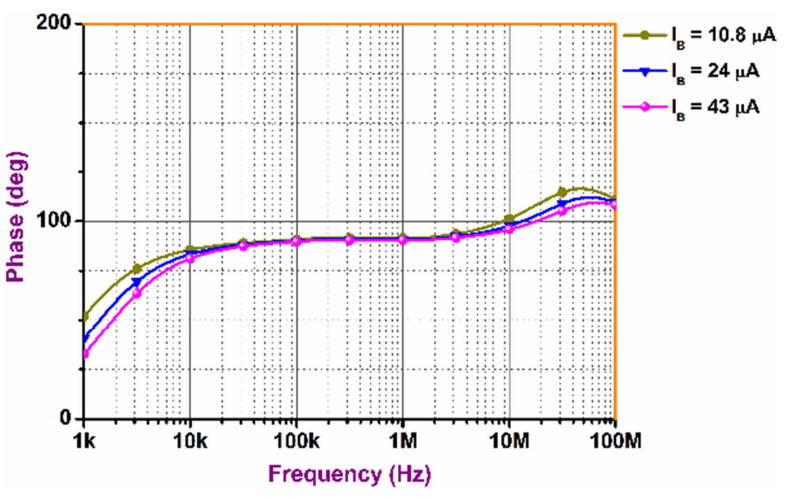

(a) With $I_{B}$

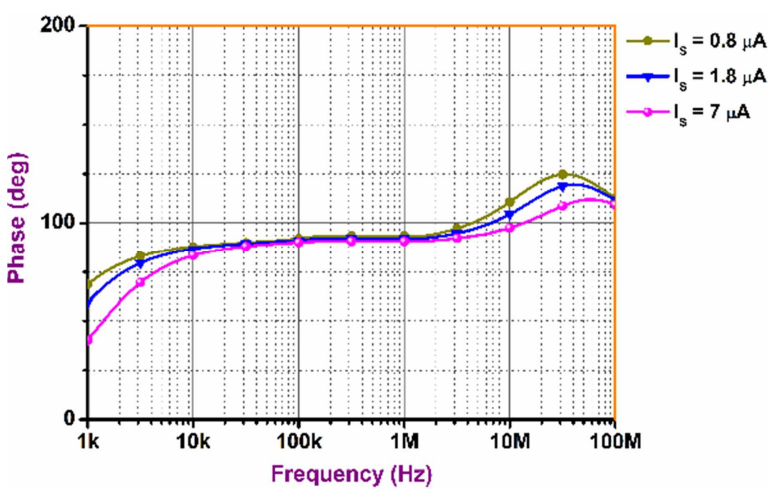

(b) With $I_{S}$

Fig. 12 Variation of phase for GIS-1

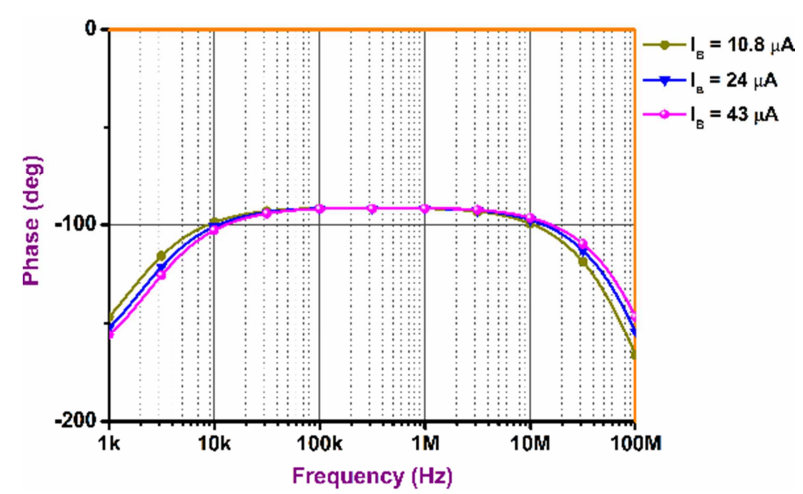

(a) With $I_{B}$

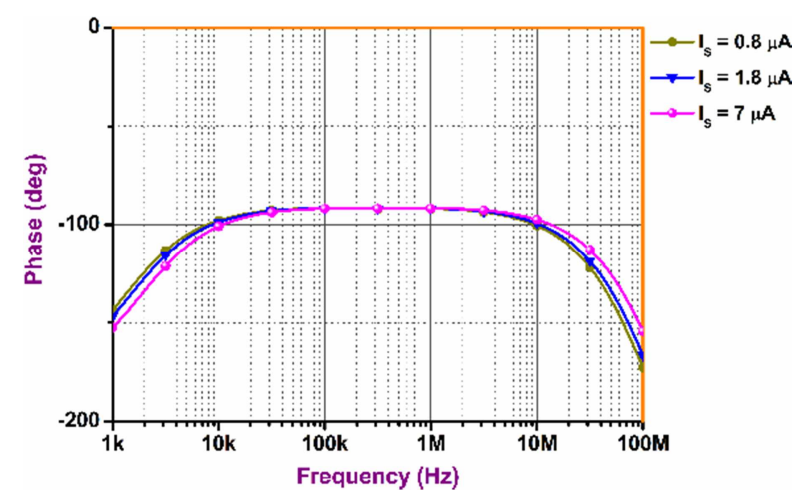

(b) With $I_{S}$

Fig. 13 Variation of phase for GIS-2

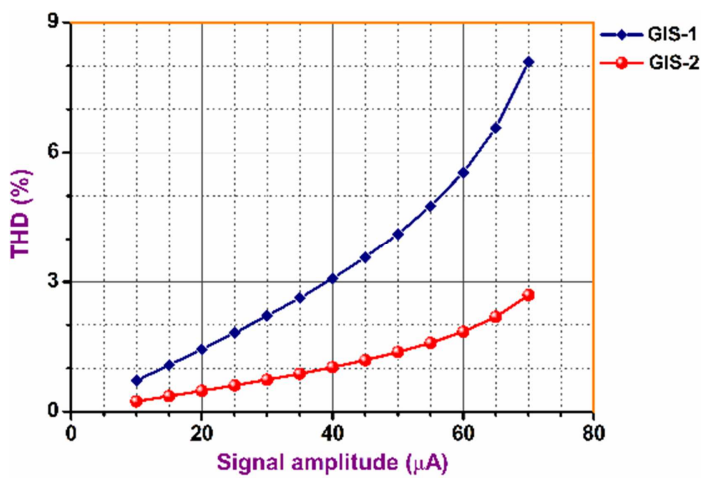

Fig. 14 THD analysis of the lossless inductance simulators' output voltage

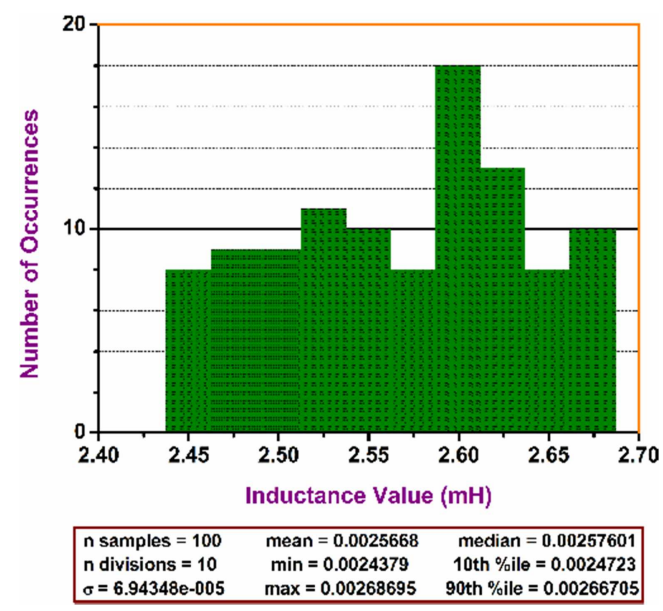

(a) For positive inductor (GIS-1)

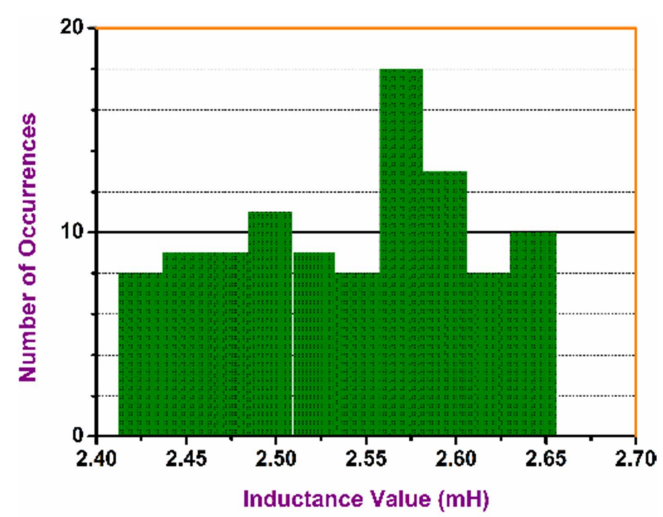

$\mathrm{n}$ samples $=100$ median $=0.00254782$ minimum $=0.00241266$ n divisions $=10$ mean $=0.00253878$ 10th $\%$ ile $=\mathbf{0 . 0 0 2 4 4 6 3 4}$ $\sigma=6.79152 \mathrm{e}-5$ maximum $=0.00265626$ 90th $\%$ ile $=0.00263681$

(b) For negative inductor (GIS-2)

Fig. 15 Monte Carlo simulation results for $10 \%$ deviation in the capacitor 


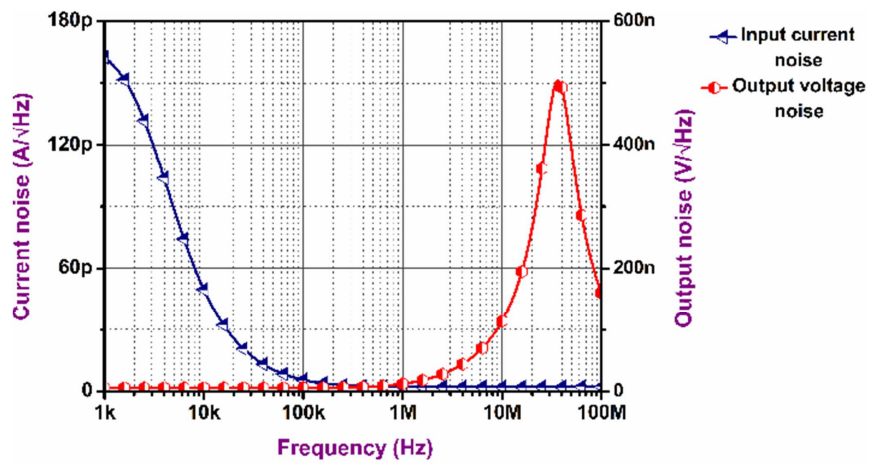

(a) For positive inductor (GIS-1)

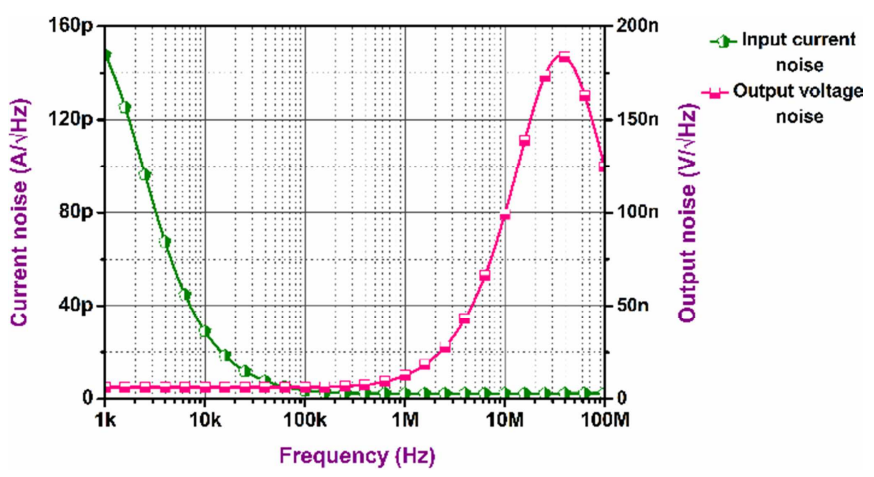

(b) For negative inductor (GIS-2)

Fig. 16 Output and input referred noise responses of the lossless inductors

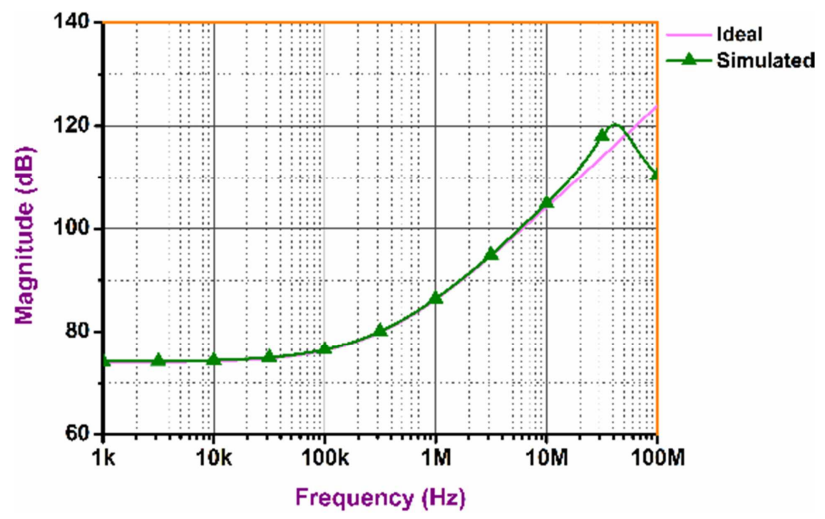

(a) Impedance

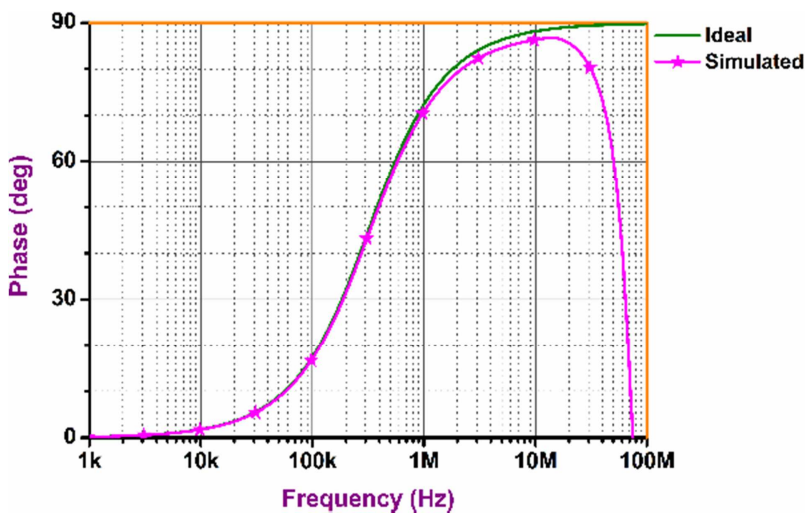

(b) Phase

Fig. 17 Frequency responses for the proposed GIS-3

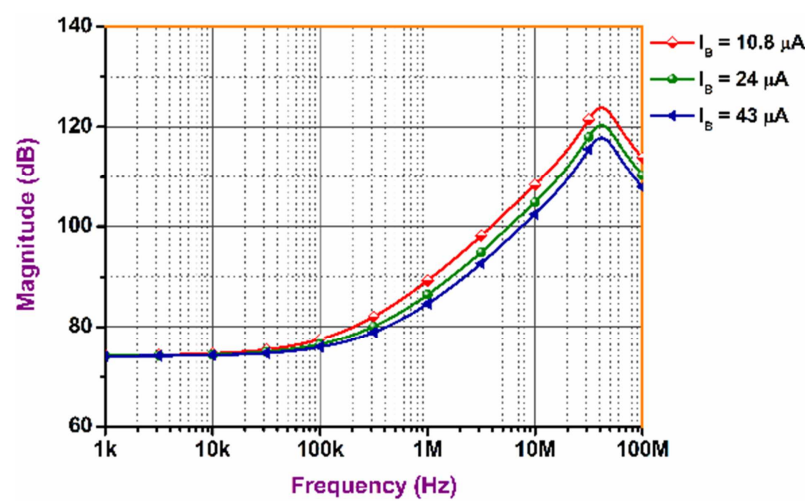

(a) For different $I_{B}$

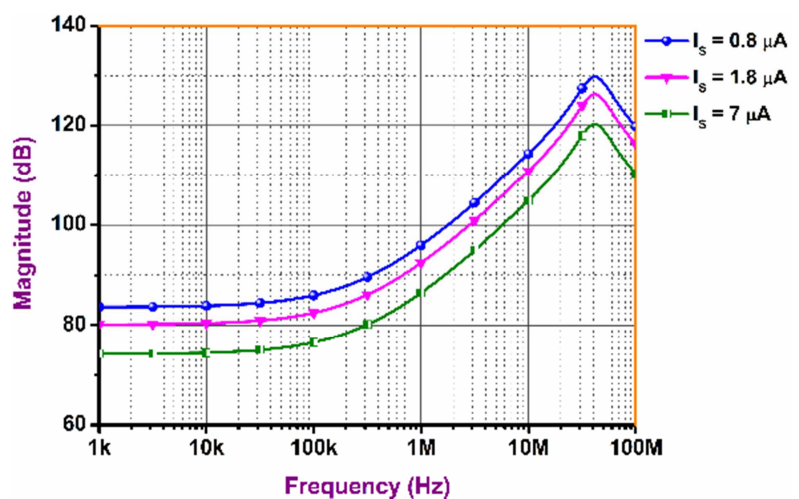

(b) For different $I_{S}$

Fig. 18 Variation of impedance magnitude for GIS-3

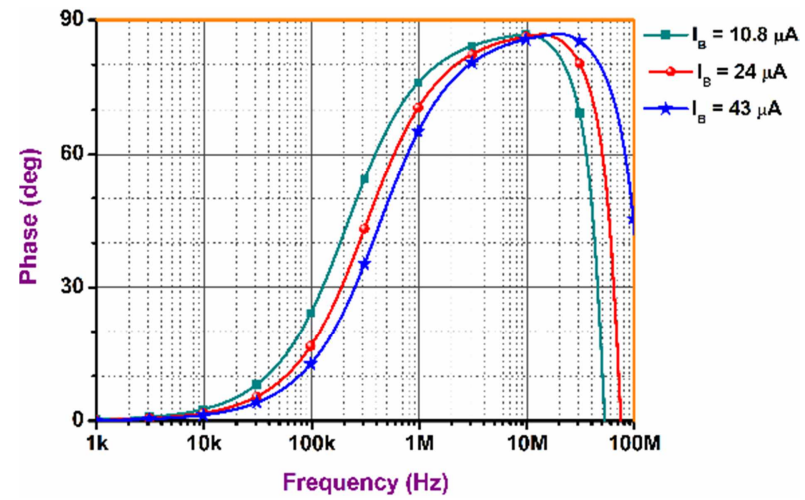

(a) For different $I_{B}$

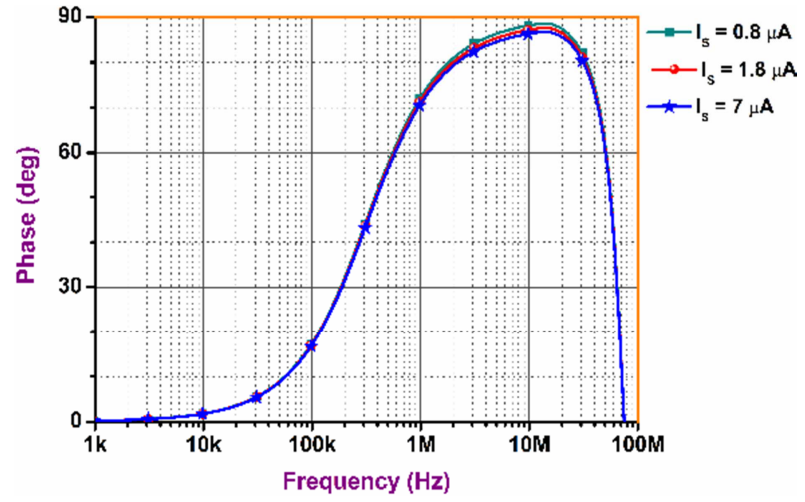

(b) For different $I_{S}$

Fig. 19 Phase-frequency responses of GIS-3 


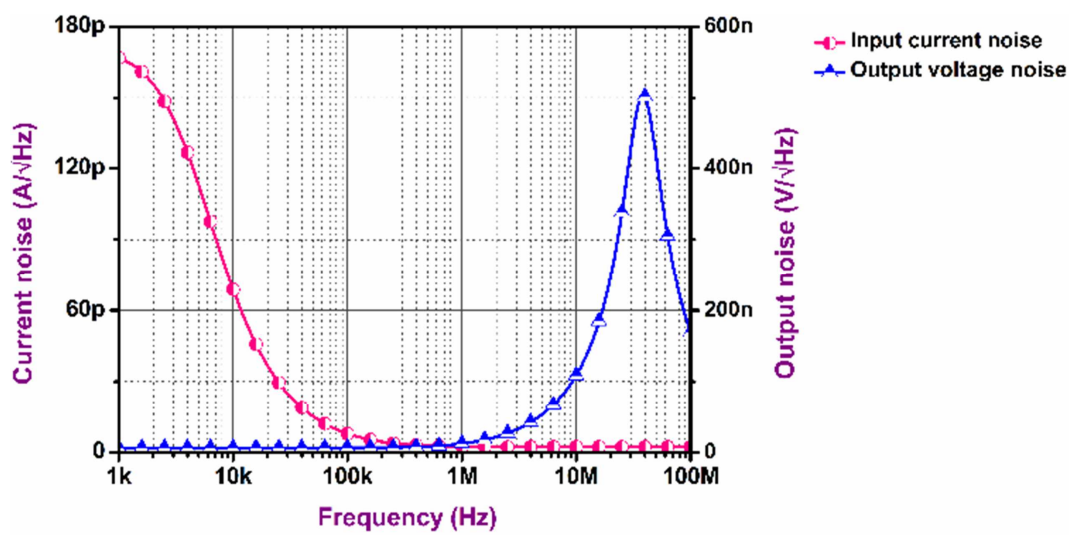

Fig. 20 Output and input referred noise responses of GIS-3

Again, the theoretical and simulated magnitude and phase responses for the input impedance of GIS-4 are given in Fig. 21. From Fig. 21(a), it is concluded that the inductor operates properly between about $20 \mathrm{kHz}$ and about $12 \mathrm{MHz}$ with the relative error within $10 \%$. The electronic tunability of GIS-4 by varying bias currents $I_{B}$ and $I_{S}$ is shown in Fig. 22.

Variation of phase for different bias currents has also been performed. Fig. 23 shows the phase variation of GIS-4 for different bias currents. Furthermore, PSPICE noise analysis has been performed on the GIS-4 and the variations in the output voltage and input referred noise is shown in Fig. 24. The output voltage noise at $1 \mathrm{MHz}$ frequency is $14.094 \mathrm{nV} / \sqrt{\mathrm{Hz}}$ and the equivalent input current noise is $2.895 \mathrm{pA} / \sqrt{\mathrm{Hz}}$.

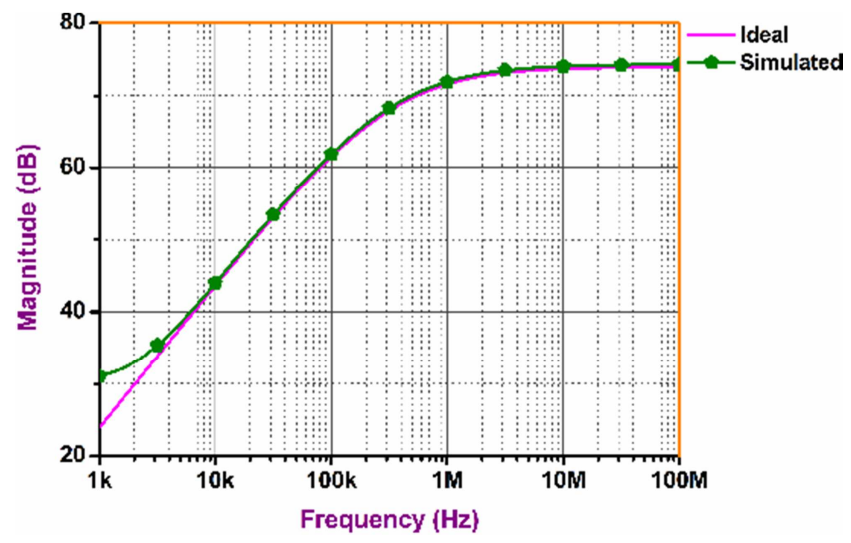

(a) Impedance magnitude

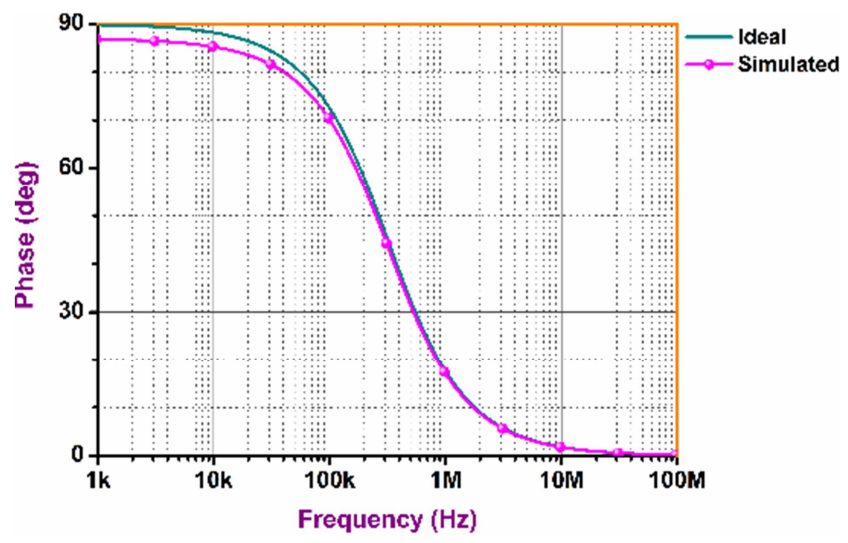

(b) Phase

Fig. 21 Frequency responses for the proposed GIS-4

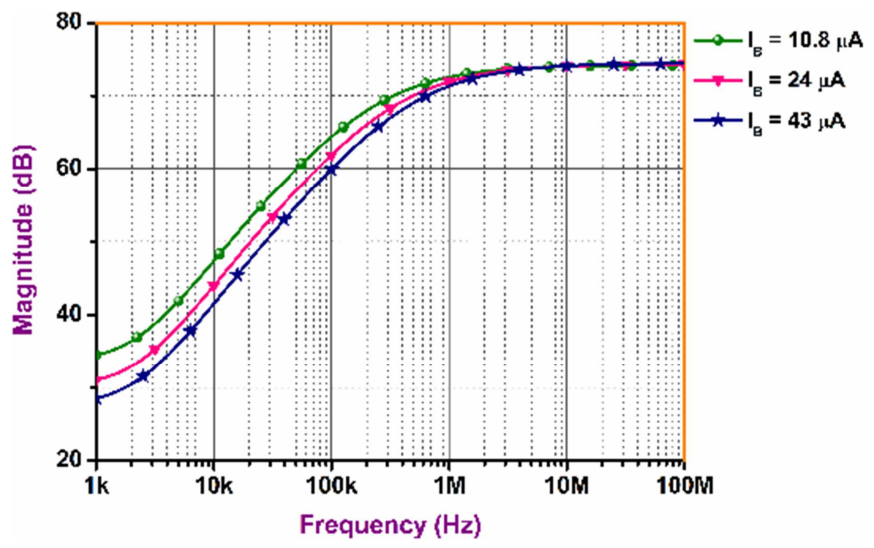

(a) For different $I_{B}$

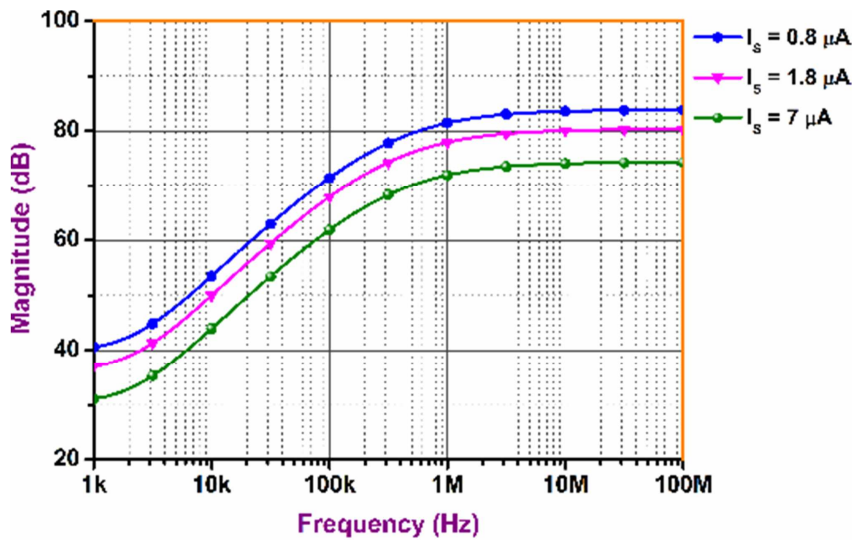

(b) For different $I_{S}$

Fig. 22 Variation of impedance magnitude of GIS-4 


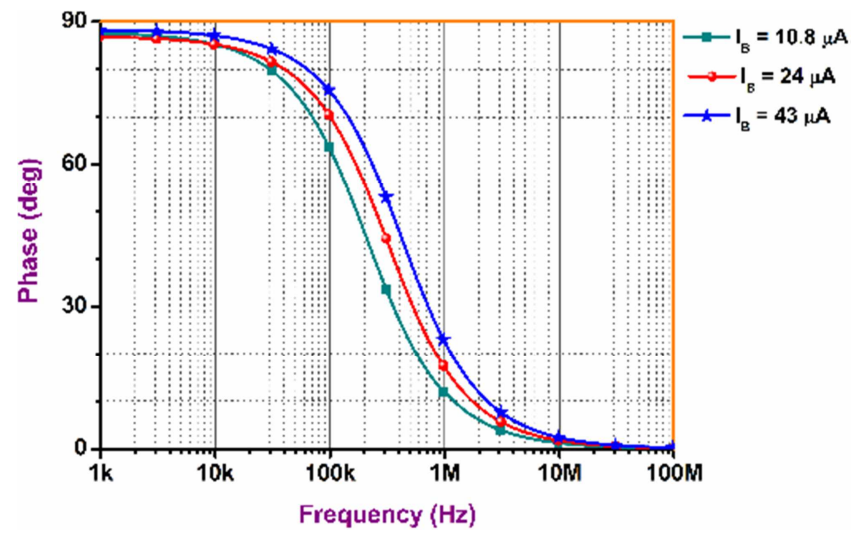

(a) For different $I_{B}$

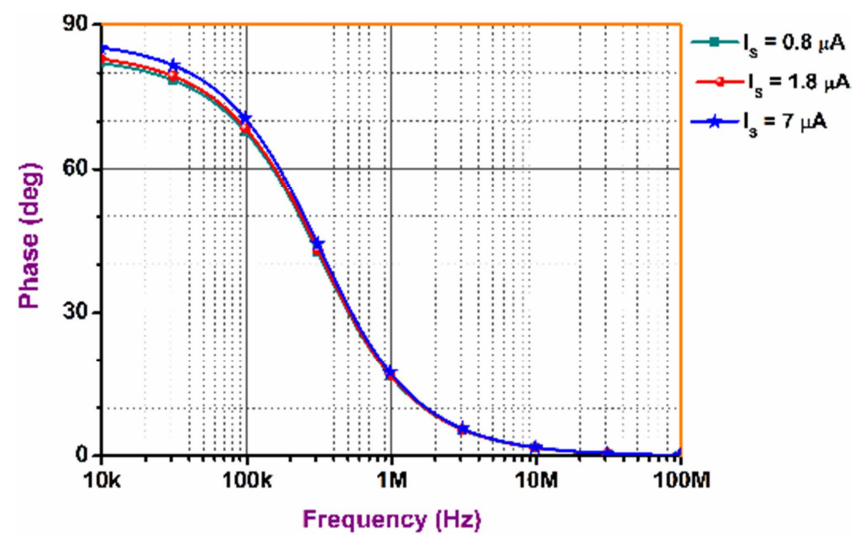

(b) For different $I_{S}$

Fig. 23 Variation of phase of GIS-4

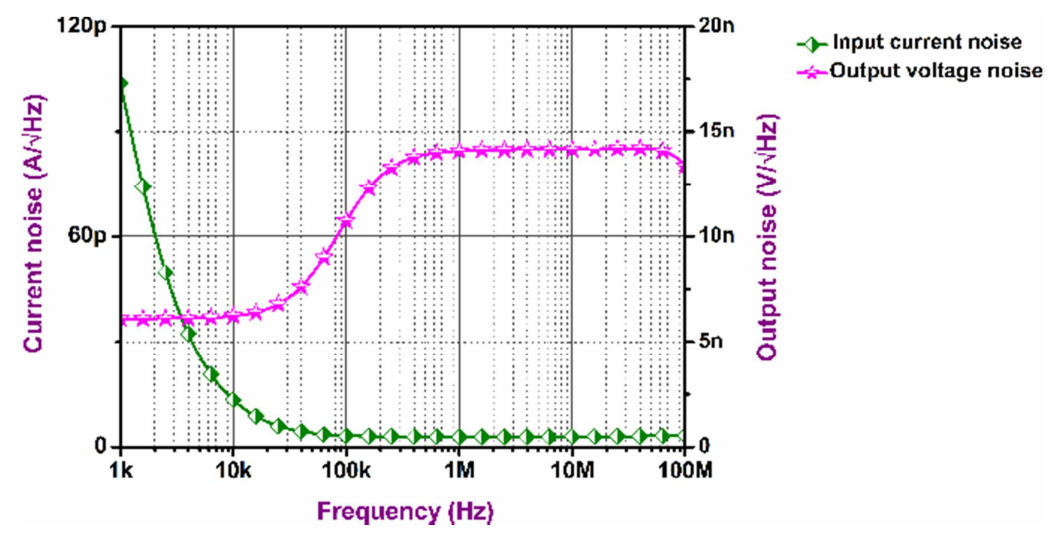

Fig. 24 Output and input referred noise responses of GIS-4

\section{Applications}

To verify the practical use of the proposed circuits (GISs 1-4), some applications are created using them. The positive inductor is used to design a BP filter, the negative inductor is used to cancel parasitic inductance, the series resistor-inductor circuit is used to design a LP filter, and the parallel resistor-inductor circuit is used to design a parallel resonant circuit.

\subsection{Lossless inductors}

\subsubsection{Positive inductor as voltage-mode BP filter design}

The positive GIS (GIS-1) is used to design the BP filter as shown in Fig. 25 [29]. The component values are taken as $\mathrm{L}=$ $2.58 \mathrm{mH}\left(I_{S}=7.113 \mu \mathrm{A}\right.$ and $\left.I_{B}=24.135 \mu \mathrm{A}\right), R=4 \mathrm{k}$, and $C=10 \mathrm{pF}$. Fig. 26 shows the ideal and simulated magnitude responses for the BP filter. The simulation result shows that the pole frequency $\left(f_{o}\right)$ of BP filter is $0.923 \mathrm{MHz}$. This value is in the error of 3.25\% from the theoretical value of $0.954 \mathrm{MHz}$. The transient analysis of the BP filter is shown in Fig. 27, where a sinusoidal voltage signal with $200 \mathrm{mV}$ peak value at $1 \mathrm{MHz}$ frequency is applied as input. The THD variations in the output voltage for various input signals at $1 \mathrm{MHz}$ frequency are depicted in Fig. 28. It reveals that the THD remains within 2.228\% up to $0.5 \mathrm{~V}$ input voltage, thus, it confirms the practical utility of the proposed circuit.

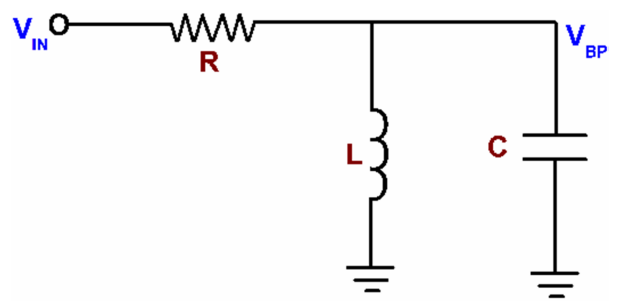

Fig. 25 The structure of the voltage mode BP filter [29] 


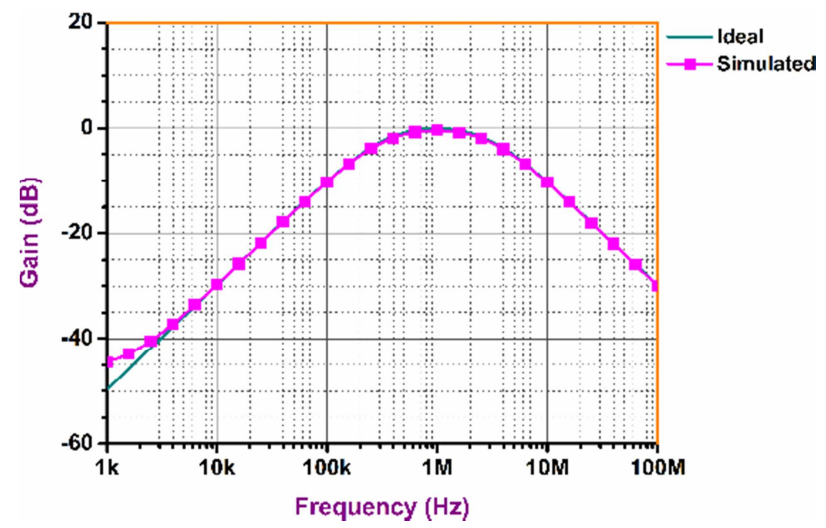

Fig. 26 The gain plot of the response of BP filter
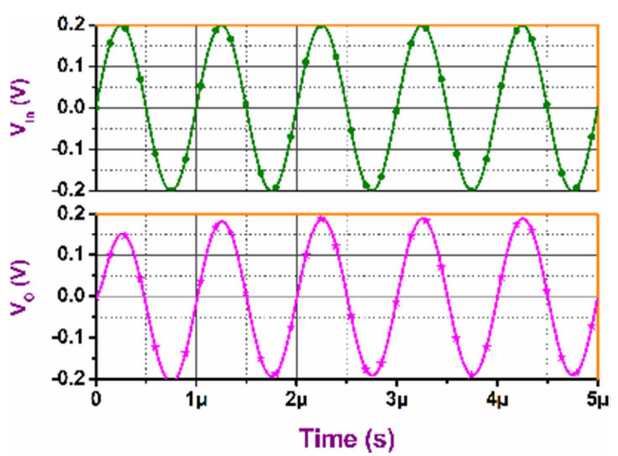

Fig. 27 Transient analysis result of the BP filter

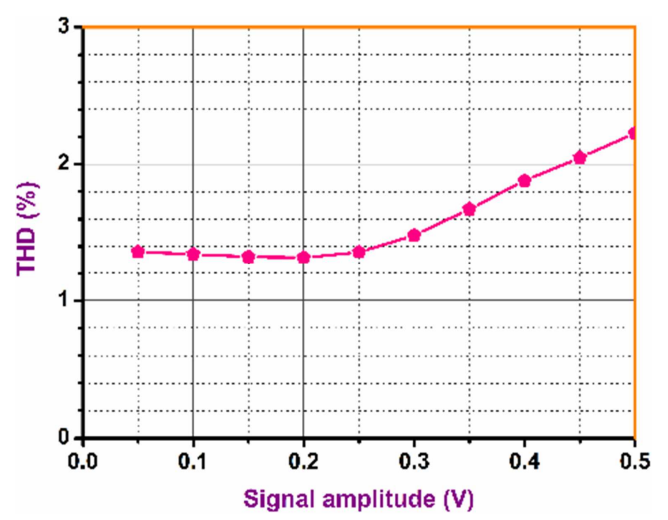

Fig. 28 THD for various input voltage amplitudes for the BP filter application

\subsubsection{Negative inductor as an inductance cancellation}

To verify the workability of the negative inductor (GIS-2), an inductance cancelation circuit [23] using the proposed negative inductor is demonstrated in Fig. 29. This cancelation circuit plays a major role in the cancellation of any unnecessary inductance presented in an electronic circuit. The values of passive components are selected as $\mathrm{R}=1 \mathrm{k} \Omega$ and $\mathrm{L}=2.58 \mathrm{mH}$. The simulation result is shown in Fig. 30, where a sinusoidal input signal with the amplitude of $50 \mathrm{mV}$ and the frequency of 500 $\mathrm{kHz}$ is applied as input. It is seen that the input voltage $\left(V_{\text {in }}\right)$ and current $\left(I_{\text {in }}\right)$ are in phase as the negative inductor cancels the effect of the positive inductor. Hence, the circuit becomes purely resistive.

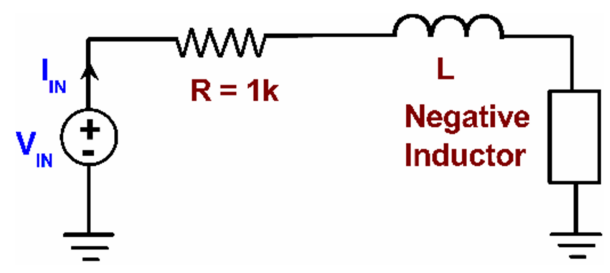

Fig. 29 Inductance cancellation circuit using negative inductor [23] 


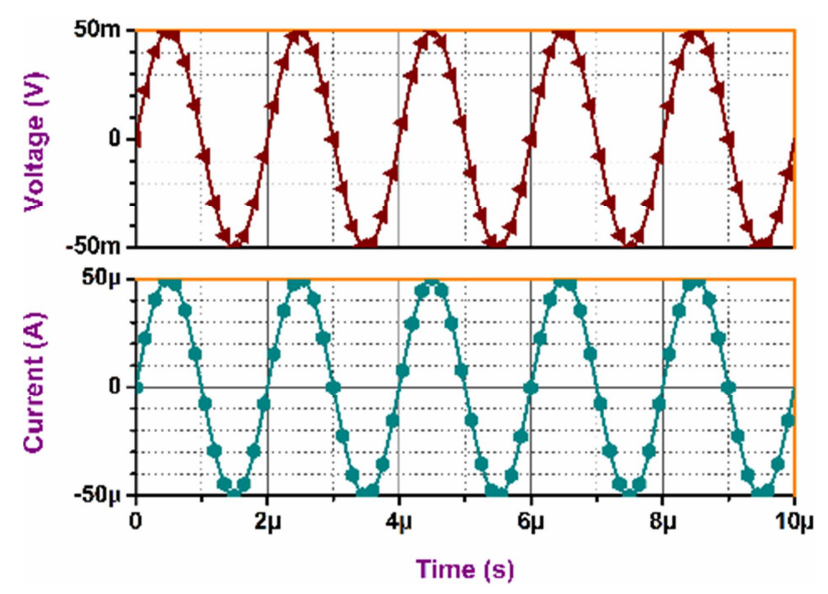

Fig. 30 Transient response of the inductance cancellation circuit

\subsection{Lossy inductors}

\subsubsection{Series $R$-L as a current-mode LP filter design}

The workability of GIS-4 is examined by reanalyzing a current mode LP filter structure as shown in Fig. 31 [1]. The passive component values are chosen as $I_{S}=7.113 \mu \mathrm{A}, I_{B}=24.135 \mu \mathrm{A}$, and C $=50 \mathrm{pF}$. The simulation and ideal responses of the LP filter are illustrated in Fig. 32.

To study the effect of mismatches in the component values within GIS-3 on the performance of the LP filter, Monte Carlo simulations have been performed by allocating 5\% tolerances to the capacitor value and performing 100 runs. The results for the 5\% tolerance are depicted in Fig. 33.

The value of the simulated cut-off frequency is found to be $614.32 \mathrm{kHz}$, and Monte Carlo analysis indicates that the median value of cut-off frequency is $617.712 \mathrm{kHz}$, which indicates that the mismatch in the component values within the proposed inductor has a small effect on the realized cut-off frequency.

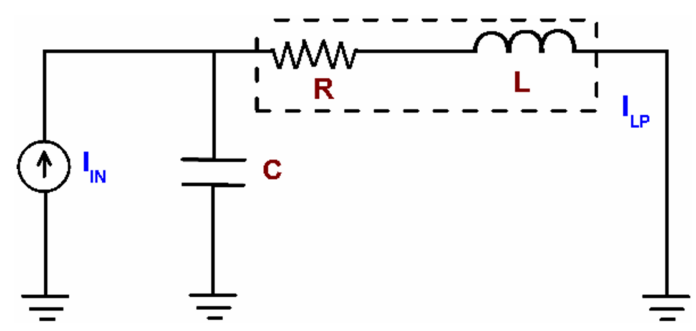

Fig. 31 The structure of the current mode LP filter [1]

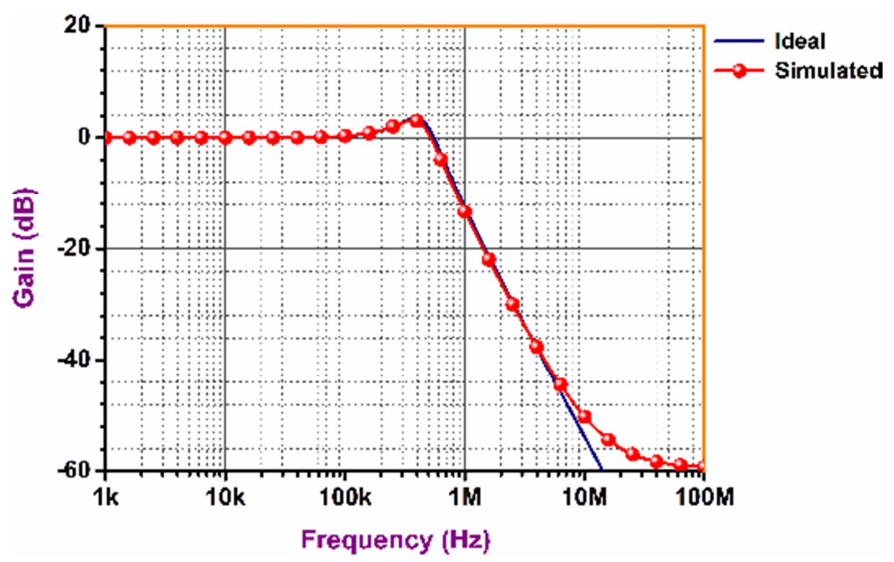

Fig. 32 The gain plot of the LP filter 


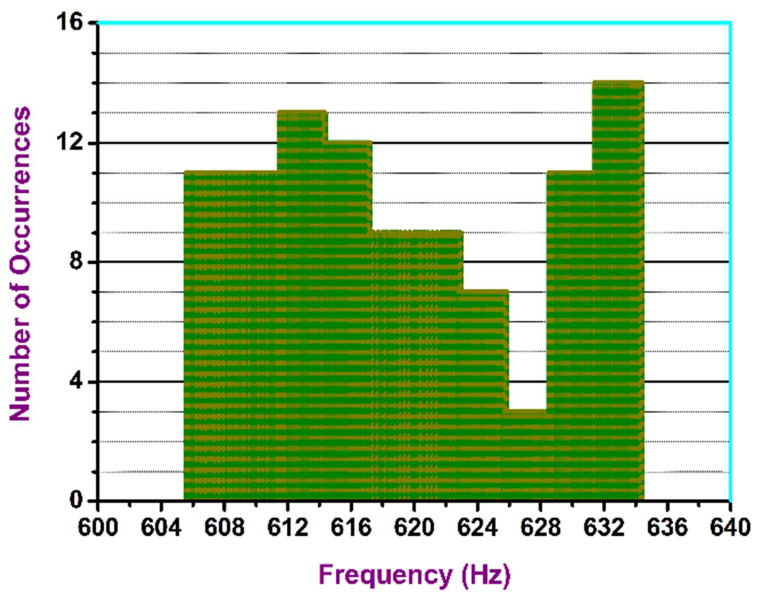

$\mathrm{n}$ samples $=100$ median $=617712$ mean $=619611$
$\mathrm{n}$ divisions $=10$ minimum $=605669$ 90th $\%$ ile $=632174$
$\sigma=8787.49$ maximum $=634333$ 10th $\%$ ile $=608331$

Fig. 33 Simulation results of Monte Carlo analysis for the LP filter

\subsubsection{Parallel $R$ - $L$ as a parallel $R L C$ resonance circuit}

As an application of the reported lossy inductor of parallel R-L type (GIS-4), it can be easily used to design the parallel RLC resonance circuit as shown in Fig. 34 [1]. In simulations, the passive component values are chosen as $L_{e q}=2.58 \mathrm{mH}, R=5 \mathrm{k} \Omega$, and $C=50 \mathrm{pF}$. The obtained results are depicted in Fig. 35 .

To verify the effect of robustness, the Monte-Carlo simulation of RLC resonance circuit has been studied on taking 100 samples and 5\% variation in capacitor value. The simulation result is shown in Fig. 36.

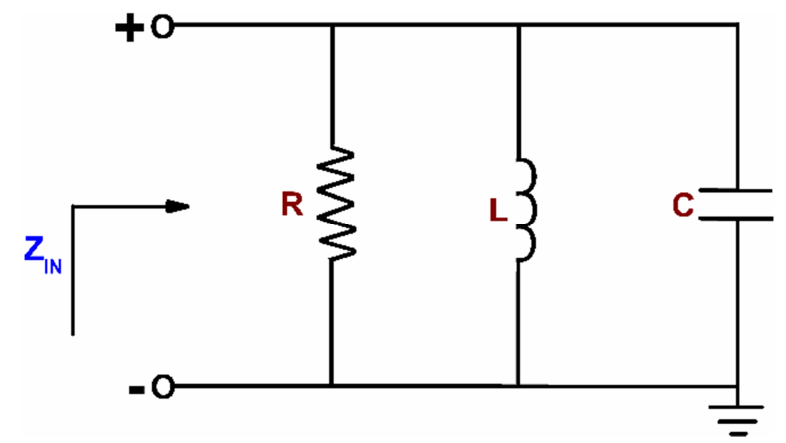

Fig. 34 Parallel RLC resonance circuit [1] realized with the proposed lossy inductor of Fig. 3(d)

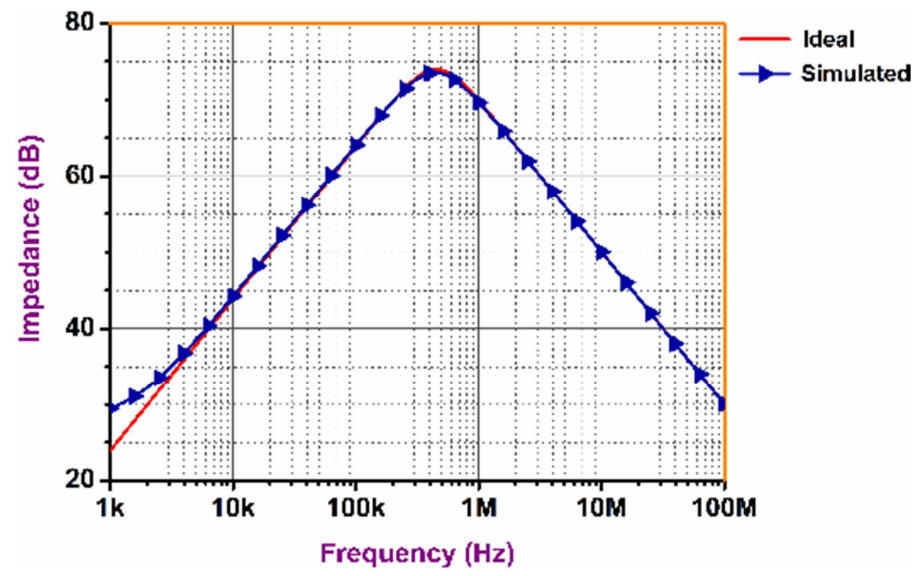

Fig. 35 Impedance-frequency characteristics of the parallel resonance circuit 


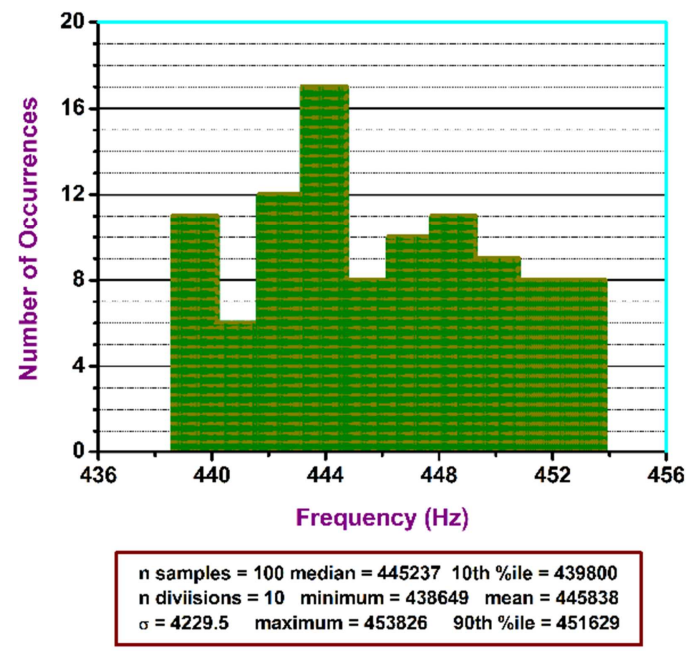

Fig. 36 Simulation results of Monte Carlo analysis for the parallel RLC resonance circuit

\section{Comparisons with Previous Publications}

Comparison of several performances of the reported inductors with few earlier grounded inductors available in the literature is summarized in Table 5. It is noted that the proposed inductor simulator circuits use a single active block and single grounded capacitor. Also, the circuits do not require any matching conditions.

Although the circuits in [1-8, 11-13, 21-24, 29] use a single active block, the circuits are not resistorless. No resistors are required for the configuration in [9-10, 14-20, 27-28], but all the circuits have one or more drawbacks. The circuit in [9] uses two active blocks and the circuits in [27] use a floating capacitor. On the other hand, a large supply voltage is required in [1, 4-16, 20, 22-25, 29] compared to the proposed circuits. The work in [2-3, 17-19, 21, 26-28] uses the same or less supply voltage compared to the proposed circuits, but the circuits in [2-3, 26-27] consume higher power. The inductor proposed in [17] cannot realize lossless inductors, whereas the work in [18-19] realize only lossless inductor. Series RL circuit cannot be realized in [21]. Also, they require one/two resistor/s. Contrarily, the circuit in [28] uses two active blocks and a floating capacitor. Therefore, the overall performance of the reported inductors is better than any of the inductor circuits cited in Table 5 , supporting the design proposal.

Table 5 Comparison between the proposed and previously reported inductor circuits

\begin{tabular}{|c|c|c|c|c|c|c|c|c|c|c|}
\hline \multirow{2}{*}{ Ref. } & \multirow{2}{*}{$\begin{array}{l}\text { No. and name } \\
\text { of active device }\end{array}$} & \multirow{2}{*}{ Inductor type } & \multicolumn{2}{|c|}{$\begin{array}{c}\mathrm{G}=\text { Grounded } \\
\mathrm{F}=\text { Floating }\end{array}$} & \multirow{2}{*}{$\begin{array}{l}\text { Matching } \\
\text { condition }\end{array}$} & \multirow{2}{*}{$\begin{array}{l}\text { Inbuilt } \\
\text { tunability }\end{array}$} & \multirow{2}{*}{$\begin{array}{l}\text { Technology } \\
\text { used }\end{array}$} & \multirow{2}{*}{$\begin{array}{l}\text { Supply } \\
\text { voltage } \\
\text { (V) }\end{array}$} & \multirow{2}{*}{$\begin{array}{l}\text { Frequency } \\
\text { range }\end{array}$} & \multirow{2}{*}{$\begin{array}{l}\text { Power } \\
\text { consumption } \\
(\mathrm{mW})\end{array}$} \\
\hline & & & $\begin{array}{l}\text { No. of } \\
\text { resistors }\end{array}$ & $\begin{array}{c}\text { No. of } \\
\text { capacitors }\end{array}$ & & & & & & \\
\hline$[1]$ & 1 DXCCDITA & $\begin{array}{c}\text { Series RL (Fig. 3(a)) } \\
\text { Parallel RL (Fig. 3(b)) } \\
\text { Lossless (Figs. 3(c)-(h)) }\end{array}$ & $1(\mathrm{G} / \mathrm{F})$ & $1(\mathrm{G})$ & $\begin{array}{l}\text { Yes } \\
\text { No } \\
\text { No }\end{array}$ & Yes & $0.35 \mu \mathrm{m}$ & \pm 1.5 & $\begin{array}{c}7 \mathrm{kHz} \\
\text { to } \\
10 \mathrm{MHz}\end{array}$ & $\begin{array}{l}\text { Not } \\
\text { reported }\end{array}$ \\
\hline$[2]$ & $1 \mathrm{MDVCC}$ & Lossless & $2(\mathrm{~F})$ & $1(\mathrm{G})$ & No & No & $0.13 \mu \mathrm{m}$ & \pm 0.75 & $\begin{array}{c}100 \mathrm{kHz} \\
\text { to } \\
10 \mathrm{MHz}\end{array}$ & 1.61 \\
\hline$[3]$ & $1 \mathrm{VDCC}$ & $\begin{array}{l}\text { Lossless (Figs. 2 (a)-(b)) } \\
\text { Series RL (Fig. 2(c)) } \\
+ \text { R series - L (Fig. 2(d)) } \\
\text { - R series + L (Fig. 2(e)) } \\
\text { - R series - L (Fig. 2(f)) }\end{array}$ & $1(\mathrm{G})$ & $1(\mathrm{G})$ & No & Yes & $0.18 \mu \mathrm{m}$ & \pm 0.9 & $\begin{array}{l}30 \mathrm{kHz} \\
\text { to } \\
20 \mathrm{MHz}\end{array}$ & 0.869 \\
\hline$[4]$ & $\begin{array}{l}1 \text { DXCCII } \\
\text { (Fig. 3(a)) } \\
1 \text { DXCCII } \\
\text { (Fig. 3(b)) }\end{array}$ & Lossless & $2 / 3(\mathrm{G})$ & $1(\mathrm{~F})$ & Yes & No & $0.35 \mu \mathrm{m}$ & \pm 1.65 & \begin{tabular}{|c|}
$30 \mathrm{kHz}$ to \\
$10 \mathrm{MHz}$ \\
$30 \mathrm{kHz}$ to \\
$30 \mathrm{MHz}$ \\
\end{tabular} & $\begin{array}{l}\text { Not } \\
\text { reported }\end{array}$ \\
\hline$[5]$ & $1 \mathrm{DXCCII}$ & $\begin{array}{c}\text { Lossless } \\
\text { (Figs. 2(a), (c)-(f)) } \\
\text { Series RL (Figs. 2(b), (f)) } \\
\text { Series RL (Figs. 2(c)-(e)) }\end{array}$ & $\begin{array}{c}2 / 3(1 / 3 \mathrm{G}, \\
1 / 2 \mathrm{~F})\end{array}$ & $1(\mathrm{G})$ & Yes & No & $0.35 \mu \mathrm{m}$ & \pm 2.5 & $\begin{array}{c}100 \mathrm{~Hz} \\
\text { to } \\
10 \mathrm{MHz}\end{array}$ & $\begin{array}{l}\text { Not } \\
\text { reported }\end{array}$ \\
\hline
\end{tabular}


Table 5 Comparison between the proposed and previously reported inductor circuits (continued)

\begin{tabular}{|c|c|c|c|c|c|c|c|c|c|c|}
\hline \multirow{2}{*}{ Ref. } & \multirow{2}{*}{$\begin{array}{l}\text { No. and name } \\
\text { of active device }\end{array}$} & \multirow{2}{*}{ Inductor type } & \multicolumn{2}{|c|}{$\begin{array}{c}\mathrm{G}=\text { Grounded }, \\
\mathrm{F}=\text { Floating }\end{array}$} & \multirow{2}{*}{$\begin{array}{l}\text { Matching } \\
\text { condition }\end{array}$} & \multirow{2}{*}{$\begin{array}{l}\text { Inbuilt } \\
\text { tunability }\end{array}$} & \multirow{2}{*}{$\begin{array}{c}\text { Technology } \\
\text { used }\end{array}$} & \multirow{2}{*}{$\begin{array}{l}\text { Supply } \\
\text { voltage } \\
\text { (V) }\end{array}$} & \multirow{2}{*}{$\begin{array}{c}\text { Frequency } \\
\text { range }\end{array}$} & \multirow{2}{*}{$\begin{array}{c}\text { Power } \\
\text { consumption } \\
(\mathrm{mW})\end{array}$} \\
\hline & & & $\begin{array}{l}\text { No. of } \\
\text { resistors }\end{array}$ & $\begin{array}{c}\text { No. of } \\
\text { capacitors }\end{array}$ & & & & & & \\
\hline [6] & $1 \mathrm{DXCCII}$ & $\begin{array}{l}\text { Lossless (Fig. 2(a)) } \\
\text { Lossless (Fig. 2(b)) } \\
+ \text { L with parallel - R } \\
\text { (Fig. 2(c)) } \\
\text { - L with parallel - R } \\
\text { (Fig. 2(d)) } \\
\text { Parallel RL (Fig. 2(e)) }\end{array}$ & $\begin{array}{c}2(1 \mathrm{G}, 1 \mathrm{~F}) \\
2(1 \mathrm{G}, 1 \mathrm{~F}) \\
2(\mathrm{~F}) \\
2(1 \mathrm{G}, 1 \mathrm{~F}) \\
2(1 \mathrm{~F})\end{array}$ & $1(\mathrm{~F})$ & $\begin{array}{l}\text { Yes } \\
\text { Yes } \\
\text { No } \\
\text { Yes } \\
\text { Yes }\end{array}$ & No & $0.35 \mu \mathrm{m}$ & \pm 1.5 & NA & $\begin{array}{l}\text { Not } \\
\text { reported }\end{array}$ \\
\hline [7] & $\begin{array}{l}1 \mathrm{CCII}+ \\
2 \mathrm{IVB}\end{array}$ & Lossless & $2(1 \mathrm{G}, 1 \mathrm{~F})$ & $1(\mathrm{~F})$ & No & No & $0.18 \mu \mathrm{m}$ & \pm 1.25 & $\begin{array}{c}200 \mathrm{kHz} \text { to } \\
20 \mathrm{MHz} \\
\text { (Fig. 3) } \\
200 \mathrm{~Hz} \text { to } \\
10 \mathrm{MHz} \\
\text { (Fig. 5) }\end{array}$ & $\begin{array}{l}\text { Not } \\
\text { reported }\end{array}$ \\
\hline$[8]$ & 1 DXCCTA & Lossless (Fig. 3) & 1 (G) (Active) & 1 (G) (Active) & No & Yes & $0.18 \mu \mathrm{m}$ & \pm 1.25 & $\begin{array}{c}10 \mathrm{~Hz} \text { to } \\
4 \mathrm{MHz}\end{array}$ & $\begin{array}{c}\text { Not } \\
\text { reported }\end{array}$ \\
\hline$[9]$ & 2 CDTA & Lossless (Fig. 1) & 0 & $1(\mathrm{G})$ & No & Yes & $0.5 \mu \mathrm{m}$ & \pm 2.5 & $\begin{array}{l}\text { Up to } \\
1 \mathrm{MHz}\end{array}$ & $\begin{array}{c}\text { Not } \\
\text { reported }\end{array}$ \\
\hline$[10]$ & 1 CСССТА & Lossless & 0 & $1(\mathrm{G})$ & No & Yes & $\begin{array}{c}\text { PR200N \& } \\
\text { NR200N }\end{array}$ & \pm 1.5 & $\begin{array}{c}\text { Up to } \\
1 \mathrm{MHZ} \\
\end{array}$ & $\begin{array}{c}\text { Not } \\
\text { reported }\end{array}$ \\
\hline$[11]$ & 1 CDBA & Parallel RL & $2(\mathrm{~F})$ & $1(\mathrm{C})$ & No & No & AD844 & \pm 12 & NA & $\begin{array}{c}\text { Not } \\
\text { reported }\end{array}$ \\
\hline$[12]$ & 1 CDBA & Lossless & $3(\mathrm{~F})$ & $1(\mathrm{G})$ & Yes & No & AD844 & \pm 12 & $\begin{array}{c}10 \mathrm{kHz} \\
\text { to } \\
80 \mathrm{kHz}\end{array}$ & $\begin{array}{l}\text { Not } \\
\text { reported }\end{array}$ \\
\hline$[13]$ & 1 FTFNTA & Lossless (Fig. 6(a)) & $1(\mathrm{G})$ & $1(\mathrm{G})$ & No & Yes & $0.18 \mu \mathrm{m}$ & \pm 1.65 & $\begin{array}{c}\begin{array}{c}1 \mathrm{~Hz} \\
\text { to } \\
1.5 \mathrm{MHz}\end{array} \\
\end{array}$ & 1.28 \\
\hline$[14]$ & 1 VDGA & $\begin{array}{l}\text { Lossless (Fig. 3) } \\
\text { Series RL (Fig. 4) }\end{array}$ & 0 & $1(\mathrm{G})$ & No & Yes & $0.35 \mu \mathrm{m}$ & \pm 1.5 & \begin{tabular}{|c|}
$100 \mathrm{~Hz}$ to \\
$2 \mathrm{MHz}$ \\
$20 \mathrm{kHz}$ \\
to $2 \mathrm{MHz}$ \\
\end{tabular} & 0.27 \\
\hline$[15]$ & $\begin{array}{c}2 \text { CC-CFA } \\
\text { (Figs. 2(a)-(b)) } \\
3 \text { CC-CFA } \\
\text { (Fig. 3) }\end{array}$ & Lossless & 0 & $1(\mathrm{G})$ & No & Yes & $\begin{array}{c}\mathrm{PR} 200 \mathrm{~N}, \\
\mathrm{NR} 200 \mathrm{~N} \& \\
0.35 \mu \mathrm{m}\end{array}$ & \pm 1.5 & $\begin{array}{l}\text { Not } \\
\text { reported }\end{array}$ & $\begin{array}{l}\text { Not } \\
\text { reported }\end{array}$ \\
\hline$[16]$ & $\begin{array}{c}1 \text { ZC-CFCCC } \\
\text { (Fig. 2) }\end{array}$ & Lossless & 0 & $1(\mathrm{G})$ & No & Yes & $0.18 \mu \mathrm{m}$ & \pm 2.5 & \begin{tabular}{|c|} 
Up to \\
$2.99 \mathrm{MHz}$ \\
\end{tabular} & 2.47 \\
\hline$[17]$ & 1 VDTA & $\begin{array}{l}\text { Series RL (Figs. 2(a)-(b)) } \\
\text { Parallel RL (Fig. 2(c)) } \\
\text { +R parallel with }-\mathrm{L} \\
\text { (Fig. 2(d)) } \\
\text { + R parallel with } \pm \mathrm{L} \\
\text { (Fig. 2(e)) }\end{array}$ & 0 & $1(\mathrm{G})$ & No & Yes & $0.18 \mu \mathrm{m}$ & \pm 0.9 & $\begin{array}{c}\text { Up to } \\
20 \mathrm{MHz}\end{array}$ & $\begin{array}{l}\text { Not } \\
\text { reported }\end{array}$ \\
\hline$[18]$ & $\begin{array}{l}1 \text { VDTA } \\
\text { (Fig. 3) }\end{array}$ & Lossless & 0 & $1(\mathrm{G})$ & No & Yes & $0.18 \mu \mathrm{m}$ & \pm 0.9 & $\begin{array}{c}600 \mathrm{kHz} \\
\text { to } \\
60 \mathrm{MHz}\end{array}$ & $\begin{array}{l}\text { Not } \\
\text { reported }\end{array}$ \\
\hline$[19]$ & 1 VDTA & Lossless & 0 & $1(\mathrm{G})$ & No & Yes & $0.18 \mu \mathrm{m}$ & \pm 0.9 & $\begin{array}{c}20 \mathrm{kHz} \\
\text { to } \\
4 \mathrm{MHz}\end{array}$ & $\begin{array}{l}\text { Not } \\
\text { reported }\end{array}$ \\
\hline$[20]$ & 1 ZC-CCCITA & Lossless & 0 & $1(\mathrm{G})$ & No & Yes & $0.35 \mu \mathrm{m}$ & \pm 1.5 & $\begin{array}{c}14 \mathrm{kHz} \\
\text { to } \\
21 \mathrm{MHz} \\
\end{array}$ & $\begin{array}{l}\text { Not } \\
\text { reported }\end{array}$ \\
\hline [21] & 1 EXCCTA & $\begin{array}{c}\text { Lossless (Figs. 1(a)-(b)) } \\
\text { Lossless (Fig. 1(c)) } \\
+ \text { L parallel with } \pm \mathrm{R} \\
\text { (Fig. 1(d)) } \\
\text { - L parallel with }-\mathrm{R} \\
\text { (Fig. 1(e)) } \\
+ \text { L parallel with }+\mathrm{R} \\
\text { (Fig. 1(f)) }\end{array}$ & $\begin{array}{l}2(\mathrm{G}) \\
1(\mathrm{G}) \\
2(\mathrm{G}) \\
2(\mathrm{G}) \\
2(\mathrm{G})\end{array}$ & $1(\mathrm{G})$ & No & Yes & $0.18 \mu \mathrm{m}$ & \pm 0.9 & $\begin{array}{c}40 \mathrm{kHz} \\
\text { to } \\
10 \mathrm{MHz}\end{array}$ & $\begin{array}{l}\text { Not } \\
\text { reported }\end{array}$ \\
\hline [22] & 1 OTRA & Lossless & $4(\mathrm{~F})$ & $1(\mathrm{~F})$ & Yes & No & $0.5 \mu \mathrm{m}$ & \pm 1.5 & $\begin{array}{c}100 \mathrm{~Hz} \\
\text { to } \\
400 \mathrm{kHz}\end{array}$ & 0.12 \\
\hline [23] & 1 OTRA & Lossless & $5(3 F, 2 G)$ & $2(\mathrm{~F})$ & Yes & No & AD844 & \pm 5 & $\begin{array}{c}\text { Up to } \\
100 \mathrm{kHz} \\
\end{array}$ & $\begin{array}{c}\text { Not } \\
\text { reported }\end{array}$ \\
\hline [24] & $\begin{array}{l}\text { 1 OTRA } \\
\text { (Fig. 2) }\end{array}$ & Parallel RL & $2(\mathrm{~F})$ & 0 & No & No & $0.5 \mu \mathrm{m}$ & \pm 1.5 & $\begin{array}{c}\text { Not } \\
\text { reported }\end{array}$ & $\begin{array}{c}\text { Not } \\
\text { reported }\end{array}$ \\
\hline
\end{tabular}


Table 5 Comparison between the proposed and previously reported inductor circuits (continued)

\begin{tabular}{|c|c|c|c|c|c|c|c|c|c|c|}
\hline \multirow{2}{*}{ Ref. } & \multirow{2}{*}{$\begin{array}{l}\text { No. and name } \\
\text { of active device }\end{array}$} & \multirow{2}{*}{ Inductor type } & \multicolumn{2}{|c|}{$\begin{array}{c}\mathrm{G}=\text { Grounded } \\
\mathrm{F}=\text { Floating }\end{array}$} & \multirow{2}{*}{$\begin{array}{l}\text { Matching } \\
\text { condition }\end{array}$} & \multirow{2}{*}{$\begin{array}{l}\text { Inbuilt } \\
\text { tunability }\end{array}$} & \multirow{2}{*}{$\begin{array}{c}\text { Technology } \\
\text { used }\end{array}$} & \multirow{2}{*}{$\begin{array}{c}\text { Supply } \\
\text { voltage } \\
\text { (V) }\end{array}$} & \multirow{2}{*}{$\begin{array}{l}\text { Frequency } \\
\text { range }\end{array}$} & \multirow{2}{*}{$\begin{array}{c}\text { Power } \\
\text { consumption } \\
(\mathrm{mW})\end{array}$} \\
\hline & & & $\begin{array}{l}\text { No. of } \\
\text { resistors }\end{array}$ & $\begin{array}{c}\text { No. of } \\
\text { capacitors }\end{array}$ & & & & & & \\
\hline$[25]$ & $\begin{array}{c}2 \text { OTRA } \\
\text { (Figs. 2(a)-(b)) }\end{array}$ & Lossless & $5(\mathrm{~F})$ & $1(\mathrm{~F})$ & Yes & No & $0.5 \mu \mathrm{m}$ & \pm 1.5 & $\begin{array}{c}1 \mathrm{kHz} \\
\text { to } \\
1 \mathrm{MHz}\end{array}$ & $\begin{array}{l}\text { Not } \\
\text { reported }\end{array}$ \\
\hline$[26]$ & $\begin{array}{l}2 \text { OTRA } \\
1 \mathrm{VF}\end{array}$ & Lossless & $1(\mathrm{~F})$ & $1(\mathrm{~F})$ & No & No & $0.18 \mu \mathrm{m}$ & \pm 0.9 & $\begin{array}{c}1 \mathrm{kHz} \\
\text { to } \\
9.8 \mathrm{MHz}\end{array}$ & 0.833 \\
\hline$[27]$ & $\begin{array}{l}1 \text { VDIBA } \\
1 \text { NMOS }\end{array}$ & $\begin{array}{l}\text { Series RL (Fig. 3(a)) } \\
\text { Parallel RL (Fig. 3(b)) }\end{array}$ & 0 & $1(\mathrm{~F})$ & No & Yes & $0.25 \mu \mathrm{m}$ & \pm 0.75 & $\begin{array}{c}1 \mathrm{kHz} \\
\text { to } \\
1 \mathrm{MHz}\end{array}$ & 5.72 \\
\hline$[28]$ & 2 VDIBA & Lossless & 0 & $1(\mathrm{~F})$ & No & Yes & $0.25 \mu \mathrm{m}$ & \pm 0.75 & $\begin{array}{c}50 \mathrm{KHz} \\
\text { to } \\
10 \mathrm{MHz}\end{array}$ & $\begin{array}{l}\text { Not } \\
\text { reported }\end{array}$ \\
\hline$[29]$ & $1 \mathrm{VDBA}$ & Lossless & $1(\mathrm{~F})$ & $1(\mathrm{~F})$ & No & Yes & OPA860 & \pm 5 & $\begin{array}{c}10 \mathrm{kHz} \\
\text { to } \\
10 \mathrm{MHz}\end{array}$ & $\begin{array}{l}\text { Not } \\
\text { reported }\end{array}$ \\
\hline $\begin{array}{c}\text { This } \\
\text { work }\end{array}$ & $1 \mathrm{MO}-\mathrm{CCCCTA}$ & \begin{tabular}{|c|} 
Lossless (Figs. 3(a)-(b)) \\
Series RL (Fig. 3(c)) \\
Parallel RL (Figs. 3(d)-(e)) \\
+ L series with - R \\
(Fig. 3(f)) \\
- L series with - R \\
(Fig. 3(g)) \\
- L parallel with + R \\
(Figs. 3(h)-(i))
\end{tabular} & 0 & $1(\mathrm{G})$ & No & Yes & $0.18 \mu \mathrm{m}$ & \pm 0.9 & $\begin{array}{c}20 \mathrm{kHz} \\
\text { to } \\
12 \mathrm{MHz}\end{array}$ & 0.784 \\
\hline
\end{tabular}

\section{Conclusions}

This study comes with an active inductor design for both lossy and lossless inductor simulator configurations which have beneficial properties over former inductor simulator designs. The proposed inductors use only one MO-CCCCTA and one capacitor. The proposed simulators can realize lossless and lossy inductors. All the recommended inductors use only grounded capacitor which is effective for noise cancellation and fabrication. The non-ideal and parasitic analysis of the inductor simulators have also been discussed. To show the beneficial application of the proposed simulators, the proposed positive inductor is used to design a BP filter, whereas the proposed negative inductor is employed to design an inductor cancellation circuit to show the advantageous application of lossless inductor. Series R-L and parallel R-L inductors are used to design the LP and parallel resonance circuit respectively, as an application example. The simulation result using $0.18 \mu \mathrm{m}$ CMOS process parameter confirms the theoretical analysis.

\section{Acknowledgments}

The authors would like to express their gratitude to the FIST-Department of Science and Technology, SAP-University Grants Commission, India for their unswerving financial support to pursue and complete this research work.

\section{Conflicts of Interest}

The authors declare no conflict of interest.

\section{References}

[1] F. Mohammad, J. Sampe, S. Shireen, and S. H. M. Ali, "Minimum Passive Components Based Lossy and Lossless Inductor Simulators Employing a New Active Block," AEU-International Journal of Electronics and Communications, vol. 82, pp. 226-240, December 2017.

[2] A. Abaci and E. Yuce, "Modified DVCC Based Quadrature Oscillator and Lossless Grounded Inductor Simulator Using Grounded Capacitor(s),” AEU-International Journal of Electronics and Communications, vol. 76, pp. 86-96, June 2017. 
[3] F. Kaçar, A. Yeşil, S. Minaei, and H. Kuntman, "Positive/Negative Lossy/Lossless Grounded Inductance Simulators Employing Single VDCC and Only Two Passive Elements," AEU-International Journal of Electronics and Communications, vol. 68, no. 1, pp. 73-78, January 2014.

[4] I. Myderrizi, S. Minaei, and E. Yuce, "DXCCII-Based Grounded Inductance Simulators and Filter Applications," Microelectronics Journal, vol. 42, no. 9, pp. 1074-1081, September 2011.

[5] B. Metin, "Supplementary Inductance Simulator Topologies Employing Single DXCCII," Radioengineering, vol. 20, no. 3, pp. 614-618, September 2011.

[6] F. Kaçar and A. Yeşil, "Novel Grounded Parallel Inductance Simulators Realization Using a Minimum Number of Active and Passive Components," Microelectronics Journal, vol. 41, no. 10, pp. 632-638, October 2010.

[7] A. Yesil, E. Yuce, and S. Minaei, "Inverting Voltage Buffer Based Lossless Grounded Inductor Simulators," AEU-International Journal of Electronics and Communications, vol. 83, pp. 131-137, January 2018.

[8] N. Kumar, J. Vista, and A. Ranjan, “A Tuneable Active Inductor Employing DXCCTA: Grounded and Floating Operation,” Microelectronics Journal, vol. 90, pp. 1-11, August 2019.

[9] D. Prasad, D. R. Bhaskar, and A. K. Singh, "New Grounded and Floating Simulated Inductance Circuits Using Current Differencing Transconductance Amplifiers,” Radioengineering, vol. 19, no. 1, pp. 194-198, April 2010.

[10] M. Siripruchyanun and W. Jaikla, "Current Controlled Current Conveyor Transconductance Amplifier (CCCCTA): A Building Block for Analog Signal Processing,” Electrical Engineering, vol. 90, no. 6, pp. 443-453, June 2008.

[11] J. K. Pathak, A. K. Singh, and R. Senani, "New Canonic Lossy Inductor Using a Single CDBA and Its Application," International Journal of Electronics, vol. 103, no. 1, pp. 1-13, February 2015.

[12] D. K. Jarwal, K. Baral, A. K. Singh, P. K. Singh, and S. Jit, "New Topologies of a Lossless Grounded Negative Inductor Using Single CDBA," 3rd International Conference on Electronics, Materials Engineering \& Nano-Technology, August 2019, pp. 1-6.

[13] H. Tarunkumar, Y. S. Singh, and A. Ranjan, "An Active Inductor Employing a New Four Terminal Floating Nullor Transconductance Amplifier (FTFNTA)," International Journal of Electronics, vol. 107, no. 5, pp. 683-702, September 2019.

[14] J. Hirunporm and M. Siripruchyanun, "Lossless/Lossy Inductance Simulators Employing Single VDGA and Grounded Element," 16th International Conference on Electrical Engineering/Electronics, Computer, Telecommunications, and Information Technology, July 2019, pp. 713-716.

[15] A. Singh, M. K. Jain, and S. Wairya, "Novel Lossless Grounded and Floating Inductance Simulators Employing a Grounded Capacitor Based in CC-CFA,” Journal of Circuits, Systems, and Computers, vol. 28, no. 6, 1950093, June 2019.

[16] A. K. Singh, P. Kumar, and R. Senani, "Electronically Tunable Grounded/Floating Inductance Simulators Using Z-Copy CFCCC," Turkish Journal of Electrical Engineering \& Computer Sciences, vol. 26, no. 2, pp. 1041-1055, March 2018.

[17] M. Srivastava, "Novel Electronically Controllable Grounded Series/Parallel Lossy Inductor Simulator Configurations," Journal of Engineering Research, vol. 6, no. 1, pp. 1-14, March 2018.

[18] M. Srivastava, D. Prasasd, and D. R. Bashkar, "New Electronically Tunable Grounded Inductor Simulator Employing Single VDTA and One Grounded Capacitor,” Journal of Engineering Science and Technology, vol. 12, no. 1, pp. 113-126, January 2017.

[19] M. Srivastava and D. Prasad, "Minimum Component, Electronically Tunable Simulator for Grounded Inductor with Low Parasitic Effects," Journal of Telecommunication, Electronic, and Computer Engineering, vol. 9, no. 2, pp. 41-46, April 2017.

[20] N. Herencsar, A. Lahiri, J. Koton, K. Vrba, and B. Metin, "Realization of Resistorless Lossless Positive and Negative Grounded Inductor Simulators Using Single ZC-CCCITA,” Radioengineering, vol. 21, no. 1, pp. 264-272, April 2012.

[21] M. Faseehuddin, J. Sampe, S. Shireen, and S. H. M. Ali, "Lossy and Lossless Inductance Simulators and Universal Filters Employing a New Versatile Active Block,” Informacije MIDEM, vol. 48, no. 2, pp. 97-114, 2018.

[22] M. Ghosh and S. K. Paul, "Design of Lossless Grounded Negative Inductance Simulator Using Single Operational Transresistance Amplifier,” Revue Roumaine des Sciences Techniques-Serie Électrotechnique et Énergétique, vol. 59, no. 4, pp. 381-390, October 2014.

[23] S. Kilinc, K. N. Salama, and U. Cam, "Realization of Fully Controllable Negative Inductance with Single Operational Transresistance Amplifier," Circuits, Systems, and Signal Processing, vol. 25, no. 1, pp. 47-57, February 2006.

[24] R. Senani, A. K. Singh, A. Gupta, and D. R. Bhaskar, "Simple Simulated Inductor, Low-Pass/Band-Pass Filter and Sinusoidal Oscillator Using OTRA," Circuits and Systems, vol. 7, no. 3, pp. 83-99, March 2016.

[25] R. Pandey, N. Pandey, S. K. Paul, A. Singh, B. Sriram, and K. Trivedi, "New Topologies of Lossless Grounded Inductor Using OTRA,” Journal of Electrical and Computer Engineering, vol. 2011, 175130, 2011. 
[26] B. C. Nagar and S. K. Paul, "Lossless Grounded Admittance Simulator Using OTRA,” Analog Integrated Circuits and Signal Processing, vol. 106, no. 3, pp. 649-659, March 2021.

[27] W. Tangsrirat, "Synthetic Grounded Lossy Inductance Simulators Using Single VDIBA," IETE Journal of Research, vol. 63, no. 1, pp. 134-141, 2017.

[28] N. Roongmuanpha, S. Unhavanich, and W. Tangsrirat, "Active Simulation of Electronically Tunable Grounded Lossless Inductor Using Voltage Differencing Inverted Buffered Amplifiers,” International Conference on Engineering, Applied Sciences, and Technology, July 2018, pp. 1-4.

[29] A. Yeşil, F. Kaçar, and K. Gürkan, "Lossless Grounded Inductance Simulator Employing Single VDBA and Its Experimental Band-Pass Filter Application,” AEU-International Journal of Electronics and Communications, vol. 68, no. 2, pp. 143-150, February 2014.

[30] H. P. Chen and W. S. Yang, "Electronically Tunable Current Controlled Current Conveyor Transconductance Amplifier-Based Mixed-Mode Biquadratic Filter with Resistorless and Grounded Capacitors,” Applied Sciences, vol. 7, no. 3, 244, March 2017.

Copyright $@$ by the authors. Licensee TAETI, Taiwan. This article is an open access article distributed under the terms and conditions of the Creative Commons Attribution (CC BY-NC) license (https://creativecommons.org/licenses/by-nc/4.0/). 